\title{
Alleviation of Salinity Induced Oxidative Stress in Chenopodium quinoa by Fe Biofortification and Biochar-Endophyte Interaction
}

\author{
Muhammad Naveed ${ }^{1, *}$, Natasha Ramzan ${ }^{1}$, Adnan Mustafa ${ }^{2}$ (D) Abdul Samad ${ }^{3}$, \\ Bushra Niamat ${ }^{1}$, Muhammad Yaseen ${ }^{1}$, Zulfiqar Ahmad ${ }^{1}$, Mirza Hasanuzzaman ${ }^{4}$, Nan Sun ${ }^{2}$, \\ Weiqi Shi ${ }^{5}$ and Minggang $X u^{2,5, *}$ \\ 1 Institute of Soil and Environmental Sciences, University of Agriculture, Faisalabad 38040, Pakistan; \\ natasharamzan@gmail.com (N.R.); bushraniamat77@gmail.com (B.N.); dr.yaseen@gmail.com (M.Y.); \\ zulfiqar1409@gmail.com (Z.A.) \\ 2 National Engineering Laboratory for Improving Quality of Arable Land, Institute of Agricultural Resources \\ and Regional Planning, Chinese Academy of Agricultural Sciences, Beijing 100081, China; \\ adnanmustafa780@gmail.com (A.M.); sunnan@caas.cn (N.S.) \\ 3 Department of Health and Environment, Bioresource Unit, AIT Austrian Institute of Technology, GmbH, \\ UFT, Konrad-Lorenz-Straße 24, 3430 Tulln, Austria; abdul.samad@ait.ac.at \\ 4 Department of Agronomy, Sher-e-Bangla Agricultural University, Dhaka 1207, Bangladesh; \\ mhzsauag@yahoo.com \\ 5 South Subtropical Crop Research Institute, Chinese Academy of Tropical Agricultural Sciences (CATAS), \\ Zhanjiang 524091, China; weiqishi@126.com \\ * Correspondence: muhammad.naveed@uaf.edu.pk (M.N.);xuminggang@caas.cn (M.X.)
}

Received: 29 October 2019; Accepted: 16 January 2020; Published: 24 January 2020

\begin{abstract}
Iron-biofortification is a sustainable food-based approach to combat iron deficiency by increasing iron content and bioavailability in agronomic crops. Siderophore producing microbes offer a sustainable and low-cost way to increase iron supply in crops. Also, certain substances released from organic amendments act as iron-chelators which increase the solubility as well as the availability of iron to plants. Present study investigated the role of siderophore-producing endophytic bacteria and biochar on iron-fortification of a novel crop quinoa in iron-limited saline conditions. The surface-disinfected seeds of quinoa were inoculated with Burkholderia phytofirmans PsJN (CFU = $\left.10^{9}\right)$ and sown in saline soil (EC $20 \mathrm{dS} \mathrm{m}^{-1}$ ) amended with biochar $(1 \% w / w)$. Results revealed that biochar and PsJN particularly when applied together significantly enhanced plant growth, grain yield, and grain nutrient contents of quinoa. Strikingly, iron concentration in quinoa grains was increased up to $71 \%$ by the combined application of biochar and PsJN. Moreover, plant physiological parameters were also improved significantly by the integrated application. However, enzymatic/non-enzymatic antioxidants activities were decreased by integrated treatment thus ameliorated salinity stress. Our study suggests that integrated application of siderophore-producing bacteria and biochar could be a promising, sustainable and cost-effective strategy which is easily integratable into the existing farming practices to achieve food fortification with micronutrients in developing countries.
\end{abstract}

Keywords: plant-microbe interaction; biofortification; salinity; biochar; quinoa; nutrient homeostasis

\section{Introduction}

Iron deficiency in plant-based foods continues to pose significant public health problems in resource-limited settings. Hidden hunger for iron is significant nutritional disorder in the world, which is considered as a prominent cause of anemia [1]. In developing countries, about $40 \%$ of young children 
and $50 \%$ of pregnant women are anemic [2]. A recent investigation showed that iron deficiency in the newborn babies is responsible for irretrievable influence on the structure, function and the development of the brain [1,3]. Iron deficiency can be cured either through pharmacological iron supplementation or through agriculture-based iron biofortification. Iron-biofortification is a sustainable food-based technique to combat iron deficiencies in humans that can be achieved through three main strategies: (i) increase of iron content in grains or edible parts of plants (ii) increase of the prebiotics concentration in the plant edible parts that favor iron absorption (iii) decrease of antinutrients like phytic acid that reduce iron absorption in the human gut by iron chelating [4].

Agriculture-based iron biofortification can be done by crop fertilization with iron chelates. However, in developing countries, this approach is not sustainable because it requires the long-term supplementation of iron fertilizers and is costly accompanying potential threats to the environment. Conversely, siderophore-producing microbes offer a sustainable and low-cost way to supply iron to the crops. Plant growth promoting bacteria (PGPB) are known to cause improvement in iron uptake in important food crops [5]. PGPB release siderophores into the surrounding environment, which scavenge iron by making iron-chelate complexes and enhance its uptake through growing roots [6]. In saline soils, oxidation states of iron fluctuate between soluble forms to relatively insoluble forms leading to the reduced iron availability in plants [7].

PGPB-based iron supply appeared to be more effective in iron-limited soils, where high $\mathrm{pH}$ and salinity reduce Fe availability to crop plants [8]. Under stress conditions, PGPB releases an enzyme 1-aminocyclopropane-1-carboxylic acid (ACC)-deaminase, which can mitigate the negative effect of salinity on root growth by lowering the ethylene concentration in the plants [9-12]. PGPB strain Burkholderia phytofirmans PsJN is well known to promote plant growth by improving essential nutrient uptakes like phosphorus, iron, and zinc or by releasing other plant growth regulators like ACC-deaminase and indole acetic acid [13]. Moreover, organic amendments when applied to soils secret certain chemical compounds which acts as chelators and sequester nutrients thus increase their bioavailability to crops [14]. Among the different forms of organic amendments, biochar is well known for improving soil health and nutrient mobilization [15,16]. It has been reported that biochar application enhances both the extent and rate of bacterial ferrihydrite reduction by mediating electron transfer processes [17].

Chenopodium quinoa (quinoa) has recently gained worldwide attention due to its high nutritious and gluten-free edible grains. It has been recognized as a key crop to improve world food security because of its potential to grow on salt-affected soils which are not suitable for other major food crops [18-20]. Until now, food-based iron biofortification is mostly studied either by Fe fertilization or through genetic modification of important crops. However, microbial-based and biochar-based iron biofortification offers more sustainable and cost-effective strategies to provide micronutrients (iron, zinc, etc.,) in developing countries. Moreover, iron biofortification of important agronomic crops like rice, wheat, and maize has been focused [21-24] but Fe biofortification of emerging food crop quinoa is hardly investigated. Here, we investigated the potential of plant growth-promoting bacterium $B$. phytofirmans PsJN and organic amendment (biochar) on the growth characters, yield parameters and iron biofortification potential of quinoa growing in iron-limited saline soil.

\section{Materials and Methods}

\subsection{Preparation of Endophytic Inoculum}

The plant growth supporting endophytic bacterium Burkholderia phytofirmans PsJN was donated by culture group of Bioresource Unit, Austrian Institute of Technology, Vienna, Austria. The inoculum of B. phytofirmans PsJN was prepared in $500 \mathrm{~mL}$ Erlenmeyer flask comprising $200 \mathrm{~mL}$ Luria-Bertani (LB) broth. The flask was incubated in an orbital shaking incubator (Firstek Scientific, Tokyo, Japan) at $180 \mathrm{rpm}$ for $48 \mathrm{~h}$ at $28 \pm 2{ }^{\circ} \mathrm{C}$. The optical density of culture was measured at wavelength $600 \mathrm{~nm}$ via 
spectrophotometer (Nicolet Evolution 300 LC, England, UK) and adjusted to $\mathrm{OD}_{0.5}$ to attain an even cell density of bacteria $\left(10^{9} \mathrm{CFU} \mathrm{mL} \mathrm{m}^{-1}\right)$ for inoculation.

The soil was prepared by sieving via a $2 \mathrm{~mm}$ mesh to remove plant debris, clods, etc., and analyzed for various characters. The soil texture as measured through hydrometer method reported by Gee and Bauder [25] was found to be clay loam comprising of $39.0 \%$ sand, $29.0 \%$ silt and $32.0 \%$ clay. The $\mathrm{pH}$ of the soil paste was 7.9 , and the electrical conductivity of soil was $1.98 \mathrm{dS} \mathrm{m}^{-1}$. Plant available Fe was $3.9 \mathrm{mg} \mathrm{kg}^{-1}$ as extracted using $0.005 \mathrm{M}$ DTPA [26]. Available phosphorus was measured by the method described by Watanabe and Olsen [27], nitrogen by Bremner and Mulvaney [28] and extractable potassium following the method of Richard [29]. Soil salinity level was maintained up to $\left(20 \mathrm{dS} \mathrm{m}^{-1}\right)$ using sodium chloride salt. Tree twigs feedstock was pyrolyzed at $400{ }^{\circ} \mathrm{C}$ for production of biochar in a laboratory setup muffle furnace with $10^{\circ} \mathrm{C} \mathrm{min}{ }^{-1}$ increase in temperature and $40 \mathrm{~min}$ residence time was maintained as described by Sanchez et al. [30]. The biochar was analyzed for physicochemical properties as $\mathrm{pH} 7.24$, EC 1.62 , cation exchange capacity $88.52 \mathrm{cmol}_{\mathrm{c} \mathrm{kg}}{ }^{-1}$, organic carbon $57.20 \%$, nitrogen $1.29 \%$, phosphorus $2.94 \%$, potassium $2.26 \%$, zinc $82.53 \mathrm{mg} \mathrm{kg}^{-1}$ and iron $89.36 \mathrm{mg} \mathrm{kg}^{-1}$. The prepared biochar was then mixed at a rate of $1 \%(w / w)$ in the soil. The seeds of quinoa (cv. UAF-Q7) were obtained from the Laboratory of Alternative Crops, Department of Crop Physiology, University of Agriculture, Faisalabad, Pakistan. Surface-disinfected seeds of quinoa were soaked in liquid suspension of PsJN $\left(10^{9} \mathrm{CFU} \mathrm{mL} \mathrm{mL}^{-1}\right)$ for one hour while un-inoculated seeds were dipped in broth without bacterial cells [31]. Six seeds were initially sown in polyethene lined pots containing $8 \mathrm{~kg}$ soil and after germination, two seedlings per pot (each representing one replicate) were maintained. The seeds were sown in mid of November 2016, and the mean maximum temperature was $22 \pm 2{ }^{\circ} \mathrm{C}$ while mean minimum temperature was $11 \pm 2{ }^{\circ} \mathrm{C}$ during the crop season. Pots were placed in rain protected wire-house of Institute of Soil and Environmental Sciences, University of Agriculture, Faisalabad, Pakistan under natural conditions. Iron was applied @ of $63 \mathrm{mg} \mathrm{kg}^{-1}$ using $\left(\mathrm{FeSO}_{4} .7 \mathrm{H}_{2} \mathrm{O}\right)$ as Fe source. Recommended rates of nitrogen, phosphorus and potassium were applied at a proportion of 75,60 and $30 \mathrm{~kg} \mathrm{ha}^{-1}$, respectively by means of urea, diammonium phosphate, and sulfate of potash. There were four treatments (i) control, (ii) biochar, (iii) PsJN and (iv) PsJN + biochar which were replicated thrice under completely randomized design (CRD).

\subsection{Plant Growth Parameters}

Plant height and dry mass of roots and shoots were recorded on maturity following standard procedures. Grains were threshed manually after harvesting the plants and air-dried under the shadow after washing. Samples of root and shoot were dried in the oven at $80^{\circ} \mathrm{C}$ for $48 \mathrm{~h}$.

\subsection{Physiological Attributes}

After 55 days of sowing, various gas exchange traits, from upper canopy entirely stretched leaves (two fully matured leaves per plant and four leaves per treatment) between 11:00 and 14:00 $\mathrm{h}$ were determined by using CIRAS-3 (PP System, Amesbury, MN, USA). Measurements were done on $1.7 \mathrm{~cm}^{2}$ area of the leaf at $400 \mu \mathrm{mol} \mathrm{mL} \mathrm{L}^{-1}$ of carbon dioxide as well as $1000 \mu \mathrm{mol} \mathrm{m}^{-2} \mathrm{~s}^{-1}$ of photosynthetically active radiations (PAR). Leaf chlorophyll contents were assessed by using SPAD meter. Each sample of the leaf was measured at least six diverse spaces for SPAD measurement.

\subsection{Extraction and Enzymatic/Non-Enzymatic Antioxidant Assays}

Extraction of various enzymatic and non-enzymatic antioxidant was done by homogenizing solid fresh leaf material in an ice-cold solution comprising of $0.2 \mathrm{M}$ potassium phosphate buffer $(\mathrm{pH} 7)$ having $0.1 \mathrm{mM}$ EDTA. Glutathione reductase was estimated according to the method reported by Smith et al. [32]. The activities of oxidized glutathione (GSSG) and reduced glutathione (GSH) were calculated following [33] method. Whereas, Ascorbate peroxidase (APX) assay was performed by Nakano and Asada [34]. Roth and Gilbert, [35] classical method was adapted to monitor the activity 
of superoxide dismutase (SOD) and the activity of glutathione-s-transferase (GST) was measured spectrophotometerically by the method given by Habig et al. [36].

\subsection{Measurement of Stress Related Metabolites}

The ROS (super oxide anion $\mathrm{O}_{2}{ }^{--}$) was measured according to the method described by Elstner and Heupel [37]. Whereas, to measure lipid peroxidation or malondialdehyde (MDA) concentration in leaves the original method given by Jambunathan [38] was applied.

\subsection{PsJN colonization of Rhizosphere, Root, and Shoot}

Rhizosphere and endophytic colonization of plant tissues by the inoculant strain PsJN were determined by dilution and plate counting technique. After harvesting, rhizospheric soil was sampled by roots agitation and collecting closely adhered soil. For colonization assay, soil slurry was prepared at a ratio of 1:3 (soil: $\mathrm{NaCl}$ ) mixing $5 \mathrm{~g}$ rhizosphere soil with $15 \mathrm{~mL}$ of $0.9 \%(w / v) \mathrm{NaCl}$ solution following agitation at $(180 \mathrm{rpm})$ for $30 \mathrm{~min}$ at $28^{\circ} \mathrm{C}$. After complete soil particles sedimentation, serial dilutions up to $10^{-6}$ were plated onto tryptic soy agar (TSA) medium. Colonies were counted after incubating the plates at $\left(28 \pm 2{ }^{\circ} \mathrm{C}\right)$ for $48 \mathrm{~h}$, and the colonization value was determined afterwards. For root $/ \mathrm{shoot}$ colonization, $2 \mathrm{~g}$ of surface-sterilized samples of each were homogenized in $10 \mathrm{~mL} 0.9 \% \mathrm{NaCl}$ solution by using a sterile mortar and pestle. The material was placed in a shaking incubator for $30 \mathrm{~min}$ at 28 ${ }^{\circ} \mathrm{C}$. After settling the solid fraction, serial dilutions up to $10^{-5}$ were spread on TSA medium. 20 visible colonies were selected per treatment randomly, and their identity with that of inoculant strain was authenticated by restriction fragment length polymorphism (RFLP) analysis of the 16S-23S rRNA intergenic spacer (IGS) region [39].

\subsection{Water Relations and Grain Quality Parameters}

Relative water contents (RWC), relative membrane permeability (RMP) and membrane stability index (MSI) were measured from fully matured flag leaves. Relative water contents were assessed by the method given by Mayak et al. [40].

$$
R W C=\frac{\text { fresh weight }- \text { dry weight }}{\text { fully tugid weight }- \text { dry weight }} \times 100
$$

For measuring RMP, leaves were cut and placed into test tubes consisting of $20 \mathrm{~mL}$ deionized water, and $\mathrm{EC}_{0}$ was measured after vortexing samples for ten seconds. $\mathrm{EC}_{1}$ of this solution was measured after $24 \mathrm{~h}$ of incubation at $4{ }^{\circ} \mathrm{C}$. The tubes were autoclaved at $121^{\circ} \mathrm{C}$ for $20 \mathrm{~min}$ to measure $\mathrm{EC}_{2}$. Following formula was used to calculate RMP as defined by Yang et al. [41].

$$
R M P(\%)=\frac{E C_{1}-E C_{0}}{E C_{2}-E C_{0}} \times 10
$$

For measuring MSI, leaf cuttings were weighed and transferred into test tubes containing $10 \mathrm{~mL}$ deionized water. These test tubes were set aside in water bath at $40{ }^{\circ} \mathrm{C}$ for $30 \mathrm{~min}$, and $\mathrm{EC}_{1}$ was noted. Then, tubes were set aside in water bath at $100{ }^{\circ} \mathrm{C}$ for $10 \mathrm{~min}$ to find out $\mathrm{EC}_{2}$. The formula to calculate MSI as defined by Sairam et al. [42] is given below.

$$
M S I=\left[1-\frac{E C_{1}}{E C_{2}}\right] \times 100
$$

The concentration of protein in total grain samples was evaluated by Bradford method [43]. Phytate was examined through a process defined by Haug and Lantzsch [44]. After grinding, $60 \mathrm{mg}$ of each grain sample was extracted with $10 \mathrm{~mL}(0.2 \mathrm{~N} \mathrm{HCl}) 25^{\circ} \mathrm{C}$ for $2 \mathrm{~h}$ and following measurement of respective concentration spectrophotometerically. Ash analysis of grain was done via methods of 
AOAC [45]. All devices utilized for chemical and biochemical examination were soaked in diluted $\mathrm{HNO}_{3}$ (pro analysis quality, Merck, Kenilworth, NJ, USA) and washed with deionized water.

\subsection{Nutrient Analysis}

Plant samples (roots and shoots) were digested following Wolf [46] method by using sulphuric acid $\left(\mathrm{H}_{2} \mathrm{SO}_{4}\right)$ and hydrogen perchloric acid $\left(\mathrm{HClO}_{4}\right)$. The digested samples (grains) were crushed in a mill and passed through $0.5 \mathrm{~mm}$ sieve to perform chemical and biochemical analysis. For quantifying iron metal, known weight of ground sub-samples of total grains was placed on digestion in a di-acid mixture having ratio 2:1 $\left(\mathrm{HNO}_{3}: \mathrm{HClO}_{4}\right)$ [47]. Concentrations of sodium and potassium in the root, shoot, and grains of quinoa were determined by a flame photometer (Jenway, PFP-7, Staffordshire, UK) and $\mathrm{Na}^{+} / \mathrm{K}^{+}$ ratio was calculated afterwards. The concentration of nitrogen in the roots, shoots and grains of quinoa was determined using Kjeldahl apparatus. Plant available phosphorus was determined using Barton reagents through Ashraf et al. [48] method. Iron concentration was measured on atomic absorption spectrophotometer (Perkin Elmer Aanalyst-100, PerkinElmer Inc, Waltham, MA, USA).

\subsection{Statistical Analysis}

Data recorded for growth, physiology, nutrients, and biochemical quality were subjected to one-way (ANOVA) analysis of variance using statistix $8.1{ }^{\circledR}$ software (Statistix, Tallahassee, FL, USA). Significant differences among treatment means were computed by post hoc Tuckey's test $(P<0.05)$.

\section{Results}

\subsection{Plant Growth Parameters}

Plant growth parameters varied considerably upon amendment of plant growth-promoting endophyte PsJN alone and in a combination with biochar. Overall, both the sole bacterial inoculation and in combination with BC increased the growth, development and nutrient uptake of quinoa at both levels of iron fertilizer but the influence was more noticeable at $63 \mathrm{mg} \mathrm{kg}^{-1}$ iron level especially in the integrated application (PsJN + BC) (Table 1). In the sole application of PsJN and BC, plant height was increased up to 12 and $39 \%$, respectively relative to the untreated control (EC, $20 \mathrm{dS} \mathrm{m}^{-1}$ ). Whereas, the integrated use of PsJN and biochar resulted in a more striking effect on plant height that was recorded up to $94 \%$ more over untreated control. Similarly, integrated application significantly increased shoots and roots dry weights up to $38 \%$ and $46 \%$, respectively at higher Fe level over control. Sole application of BC and PsJN increased shoots dry weight up to $13 \%$ and $10 \%$ at $\mathrm{Fe} 3.9 \mathrm{mg} \mathrm{kg}^{-1}$ while $27 \%$ and $24 \%$ increase was observed at Fe $63.9 \mathrm{mg} \mathrm{kg}^{-1}$. Similarly, same treatments showed increase in roots dry weight $(15 \%, 8 \%)$ and $(38 \%, 31 \%)$ at both Fe levels, respectively as compared to control. Relatively little increase (7\% and 10\%) in grain yield was observed by separate application of BC and PsJN at low Fe level while up to 22 and $28 \%$ increase was observed when same treatments were integrated with Fe at higher level as compared to control. The maximum increase in grain yield (35\%) was recorded through combined use of BC, PsJN and Fe $\left(63.9 \mathrm{mg} \mathrm{kg}^{-1}\right)$ over control.

\subsection{Physiological Attributes}

Plant physiological characters showed the greatest improvement with the integrated application of endophyte PsJN and tree-twigs biochar under saline environment. The integrated application significantly increased photosynthetic and transpiration rate up to $41 \%$ and $138 \%$, respectively compared to control. However, solely the biochar and PsJN boosted rate of photosynthesis up to 9 and $20 \%$, respectively relative to control when both treatments were combined with Fe, relatively higher increase $26 \%$ and $34 \%$ were observed compared to control. Similarly, in transpiration rate, BC and PsJN showed 115 and $100 \%$ increase at Fe $63.9 \mathrm{mg} \mathrm{kg}^{-1}$ relative to control. The other physiological parameters such as stomatal and sub-stomatal conductance, integrated use performed better as compared to the sole application of bacteria and BC at both Fe levels compared to control (Table 1). 
Table 1. The effect of biochar-Burkholderia phytofirmans PsJN integration on growth and physiological parameters of Chenopodium quinoa under salinity stress.

\begin{tabular}{|c|c|c|c|c|c|c|c|c|c|}
\hline Treatment & $\mathrm{Fe}\left(\mathrm{mg} \mathrm{kg}^{-1}\right)$ & $\begin{array}{l}\text { Plant Height } \\
\quad(\mathrm{cm})\end{array}$ & $\begin{array}{l}\text { Root Dry Weight } \\
\quad\left(\mathrm{g} \mathrm{pot}^{-1}\right)\end{array}$ & $\begin{array}{c}\text { Shoot Dry } \\
\text { Weight }\left(\mathrm{g} \mathrm{pot}^{-1}\right)\end{array}$ & $\begin{array}{l}\text { Grain Yield } \\
\left(\mathrm{g} \mathrm{pot}^{-1}\right)\end{array}$ & $\begin{array}{c}\text { Photosynthetic } \\
\text { Rate }(\mu \mathrm{mol} \\
\left.\mathrm{CO}_{2} \mathrm{~m}^{-2} \mathrm{~s}^{-1}\right)\end{array}$ & $\begin{array}{c}\text { Transpiration } \\
\text { Rate }(\mu \mathrm{mol} \\
\left.\mathrm{H}_{2} \mathrm{O} \mathrm{m}^{-2} \mathrm{~s}^{-1}\right)\end{array}$ & 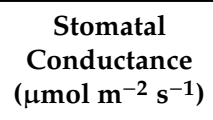 & $\begin{array}{l}\text { Internal } \mathrm{CO}_{2} \\
\text { Concentration } \\
\left(\mu \mathrm{mol} \mathrm{mol}^{-1}\right)\end{array}$ \\
\hline C & $\begin{array}{l}3.9 \\
63.9 \\
\end{array}$ & $\begin{array}{c}35.3 \pm 1.45 \mathrm{~g} \\
45 \pm 1.94 \mathrm{ef}\end{array}$ & $\begin{array}{c}1.3 \pm 0.086 \mathrm{~d} \\
1.4 \pm 0.086 \mathrm{bc}\end{array}$ & $\begin{array}{c}3.7 \pm 0.165 \mathrm{c} \\
4.4 \pm 0.258 \mathrm{ab}\end{array}$ & $\begin{array}{l}6.8 \pm 0.332 \mathrm{e} \\
7.8 \pm 0.265 \mathrm{c}\end{array}$ & $\begin{array}{c}11.6 \pm 0.185 \mathrm{e} \\
13.4 \pm 0.317 \mathrm{~cd}\end{array}$ & $\begin{array}{c}1.3 \pm 0.88 \mathrm{e} \\
1.9 \pm 0.56 \mathrm{~cd}\end{array}$ & $\begin{array}{c}75.3 \pm 2.02 \mathrm{e} \\
83.7 \pm 2.18 \mathrm{de}\end{array}$ & $\begin{array}{c}274.7 \pm 5.54 \mathrm{a} \\
254.3 \pm 4.91 \mathrm{bc}\end{array}$ \\
\hline $\mathrm{BC}$ & $\begin{array}{l}3.9 \\
63.9\end{array}$ & $\begin{array}{c}48.9 \pm 1.67 \mathrm{de} \\
61.2 \pm 2.03 \mathrm{~b}\end{array}$ & $\begin{array}{l}1.5 \pm 0.106 \mathrm{bc} \\
1.8 \pm 0.128 \mathrm{ab}\end{array}$ & $\begin{array}{l}4.2 \pm 0.248 \mathrm{bc} \\
4.7 \pm 0.355 \mathrm{ab}\end{array}$ & $\begin{array}{l}7.3 \pm 0.270 \mathrm{~d} \\
8.3 \pm 0.292 \mathrm{~b}\end{array}$ & $\begin{array}{l}12.6 \pm 0.523 \mathrm{de} \\
14.6 \pm 0.425 \mathrm{bc}\end{array}$ & $\begin{array}{l}2.1 \pm 0.91 c \\
2.8 \pm 0.44 b\end{array}$ & $\begin{array}{l}86.7 \pm 2.60 \mathrm{~cd} \\
109.3 \pm 3.52 \mathrm{a}\end{array}$ & $\begin{array}{l}246.3 \pm 4.33 \mathrm{~cd} \\
231.7 \pm 3.92 \mathrm{de}\end{array}$ \\
\hline PsJN & $\begin{array}{l}3.9 \\
63.9\end{array}$ & $\begin{array}{l}39.5 \pm 2.04 \mathrm{fg} \\
56.9 \pm 1.76 \mathrm{bc}\end{array}$ & $\begin{array}{l}1.4 \pm 0.076 \mathrm{~cd} \\
1.7 \pm 0.113 \mathrm{ab}\end{array}$ & $\begin{array}{l}4.1 \pm 0.230 \mathrm{bc} \\
4.6 \pm 0.302 \mathrm{ac}\end{array}$ & $\begin{array}{l}7.5 \pm 0.384 \mathrm{~cd} \\
8.7 \pm 0.352 \mathrm{ab}\end{array}$ & $\begin{array}{l}13.9 \pm 0.642 \mathrm{~cd} \\
15.5 \pm 0.550 \mathrm{ab}\end{array}$ & $\begin{array}{l}1.7 \pm 1.11 \mathrm{~d} \\
2.6 \pm 0.64 \mathrm{~b}\end{array}$ & $\begin{array}{c}81.3 \pm 2.02 \mathrm{de} \\
99.3 \pm 3.17 \mathrm{~b}\end{array}$ & $\begin{array}{l}264 \pm 6.08 \mathrm{ab} \\
241 \pm 4.16 \mathrm{~cd}\end{array}$ \\
\hline
\end{tabular}

Quantities sharing similar letters are not different with each other. C: Control; BC: Biochar (1\% w/w); PsJN: Burkholderia phytofirmans; Fe: Ferrous sulphate (15 kg ha $\left.{ }^{-1}\right)$. Values are mean of three repeats $\pm \mathrm{SD}$. 


\subsection{Water Relations, Chlorophyll Content and Grain Quality Parameters}

Data indicated that the integrated application of BC and PsJN also significantly increased the water relations of Chenopodium quinoa in terms of RWC, MSI and RMP up to 55\%, $127 \%$, and $64 \%$ respectively relative to their control treatments at Fe $63.9 \mathrm{mg} \mathrm{kg}^{-1}$ (Table 2). The sole application of BC and PsJN showed increase in RWC (20\% and $14 \%)$, MSI (45\% and $30 \%)$ and RMP $(23 \%$ and $9 \%)$ at low Fe relative to their controls. However, BC and PsJN when combined with Fe showed increase $42 \%$ and $30 \%$ in RWC, $98 \%$ and $110 \%$ in MSI and $58 \%$ and $43 \%$ in RMP, respectively as compared to control. Likewise, the grain protein and ash levels were improved up to $61 \%$ and $57 \%$ over control by the simultaneous use of biochar and PsJN at higher Fe level. However, alone application of biochar and PsJN enhanced protein levels up to $9 \%$ and $18 \%$ at low Fe while up to $42 \%$ and $52 \%$, respectively at higher Fe than control. Likewise, sole use of biochar and PsJN increased grain ash contents by $9 \%$ and $17 \%$ at low $\mathrm{Fe}$, while $38 \%$ and $49 \%$ at high Fe level, respectively than control. In case of chlorophyll content, sole use of BC and PsJN enhanced 15 and 23\% chlorophyll content as compared to control at higher Fe level. Maximum increase (32\%) in chlorophyll content was recorded through combined use of BC and PsJN at Fe $63.9 \mathrm{mg} \mathrm{kg}^{-1}$ (Table 2).

Table 2. The effect of biochar-Burkholderia phytofirmans PsJN integration on water relations, chlorophyll contents and grain quality parameters of Chenopodium quinoa under salinity stress.

\begin{tabular}{|c|c|c|c|c|c|c|c|}
\hline Treatment & $\mathrm{Fe}\left(\mathrm{mg} \mathrm{kg}^{-1}\right)$ & RWC (\%) & RMP (\%) & MSI (\%) & Protein (\%) & Ash (\%) & $\begin{array}{l}\text { Chlorophyll } \\
\text { (SPAD) }\end{array}$ \\
\hline $\mathrm{C}$ & $\begin{array}{c}3.9 \\
63.9\end{array}$ & $\begin{array}{c}47.33 \pm 1.53 \mathrm{~d} \\
54.16 \pm 1.84 \mathrm{~cd}\end{array}$ & $\begin{array}{l}42.43 \pm 1.54 \mathrm{~d} \\
55.90 \pm 2.08 \mathrm{~b}\end{array}$ & $\begin{array}{c}18.60 \pm 0.66 \mathrm{e} \\
28.80 \pm 1.10 \mathrm{~cd}\end{array}$ & $\begin{array}{c}9 \pm 0.38 \mathrm{e} \\
12.1 \pm 0.35 \mathrm{c}\end{array}$ & $\begin{array}{l}2.3 \pm 0.15 \mathrm{e} \\
3 \pm 0.23 \mathrm{ad}\end{array}$ & $\begin{array}{c}47.5 \pm 1.47 \mathrm{~d} \\
51.6 \pm 1.73 \mathrm{~cd}\end{array}$ \\
\hline $\mathrm{BC}$ & $\begin{array}{c}3.9 \\
63.9\end{array}$ & $\begin{array}{c}56.60 \pm 1.59 \mathrm{c} \\
67.13 \pm 2.08 \mathrm{ab}\end{array}$ & $\begin{array}{c}52.20 \pm 1.99 \mathrm{bc} \\
66.80 \pm 2.03 \mathrm{a}\end{array}$ & $\begin{array}{c}26.90 \pm 0.81 \mathrm{~cd} \\
36.90 \pm 1.10 \mathrm{~b}\end{array}$ & $\begin{array}{c}9.8 \pm 0.23 \mathrm{de} \\
12.8 \pm 0.35 \mathrm{bc}\end{array}$ & $\begin{array}{l}2.5 \pm 0.15 \mathrm{de} \\
3.2 \pm 0.23 \mathrm{ab}\end{array}$ & $\begin{array}{c}50.9 \pm 1.51 \mathrm{~d} \\
54.7 \pm 1.77 \mathrm{bc}\end{array}$ \\
\hline PsJN & $\begin{array}{c}3.9 \\
63.9\end{array}$ & $\begin{array}{l}53.80 \pm 1.59 \mathrm{~cd} \\
61.53 \pm 1.79 \mathrm{bc}\end{array}$ & $\begin{array}{l}46.16 \pm 1.48 \mathrm{~cd} \\
60.73 \pm 1.85 \mathrm{ab}\end{array}$ & $\begin{array}{c}24.10 \pm 0.64 \mathrm{~d} \\
39.20 \pm 1.18 \mathrm{ab}\end{array}$ & $\begin{array}{c}10.6 \pm 0.36 \mathrm{~d} \\
13.7 \pm 0.27 \mathrm{ab}\end{array}$ & $\begin{array}{l}2.7 \pm 0.15 \mathrm{ce} \\
3.4 \pm 0.26 \mathrm{ab}\end{array}$ & $\begin{array}{l}52.3 \pm 1.33 \mathrm{~cd} \\
58.5 \pm 1.83 \mathrm{ab}\end{array}$ \\
\hline $\mathrm{BC}+\mathrm{PsJN}$ & $\begin{array}{c}3.9 \\
63.9\end{array}$ & $\begin{array}{c}59.00 \pm 1.91 \mathrm{bc} \\
73.30 \pm 1.84 \mathrm{a}\end{array}$ & $\begin{array}{c}54.43 \pm 1.51 \mathrm{bc} \\
69.70 \pm 2.15 \mathrm{a}\end{array}$ & $\begin{array}{l}29.80 \pm 0.63 \mathrm{c} \\
42.23 \pm 1.39 \mathrm{a}\end{array}$ & $\begin{array}{l}12.4 \pm 0.32 \mathrm{c} \\
14.5 \pm 0.37 \mathrm{a}\end{array}$ & $\begin{array}{c}2.8 \pm 0.17 \text { be } \\
3.6 \pm 0.21 \mathrm{a}\end{array}$ & $\begin{array}{l}53.2 \pm 1.87 \mathrm{c} \\
62.6 \pm 2.01 \mathrm{a}\end{array}$ \\
\hline
\end{tabular}

Quantities sharing similar letters are not different with each other. Values are mean of three repeats \pm SD. C: Control; BC: Biochar (1\% w/w); PsJN: Burkholderia phytofirmans; Fe: Ferrous sulphate $\left(15 \mathrm{~kg} \mathrm{ha}^{-1}\right)$. RWC $=$ Relative water contents, RMP $=$ Relative membrane permeability and MSI = Membrane stability index.

\subsection{Nutrient Analysis}

Data regarding Fe concentration in roots revealed that integrated application significantly increased root Fe concentration relative to control at both iron levels. However, the maximum increment $71 \%$ in root iron content was noticed when Fe was applied at $63.9 \mathrm{mg} \mathrm{kg}^{-1}$ along with BC and PsJN. The sole application of BC and PsJN showed $40 \%$ and $48 \%$ in shoot and $43 \%$ and $53 \%$ increase in grain $\mathrm{Fe}$ contents, respectively as compared to control whereas integrated application strikingly enhanced $\mathrm{Fe}$ concentration up to 70 and $71 \%$, respectively in both parts over control (Figure 1).

Bacterial inoculation, especially in combination with $\mathrm{BC}$ enhanced major nutrients like nitrogen $(\mathrm{N})$, phosphorus $(\mathrm{P})$ and potash $(\mathrm{K})$ concentration both in below and aboveground parts of the plant (Tables 3 and 4). Sole application of BC and PsJN showed increase (17\% and 13\%), (13\% and 8\%) and (31\% and $19 \%$ ) in root, shoot and grain N, respectively over control. Fe application along with BC and PsJN showed more promising increase in plant upper tissue compared to control. Maximum increase $66 \%, 58 \%$ and $90 \%$ in root, shoot and grain was observed through integrated application of $\mathrm{BC}$ and PsJN at $63.9 \mathrm{mg} \mathrm{Fe} / \mathrm{kg}$ compared to control. Similar trend was observed regarding P and K concentration in upper plant tissue of quinoa by BC and PsJN application at 3.9 and $63.9 \mathrm{mg} \mathrm{Fe} / \mathrm{kg}$ compared to control. Application of $\mathrm{BC}$ and PsJN inoculum decreased sodium (Na) concentration in roots as well as in shoots. The integrated application of biochar and PsJN showed highest decrease in Na level particularly at higher Fe dose that was $40 \%, 58 \%$, and $66 \%$ less than control in the roots, shoots and grains, respectively (Table 4). Contrarily, plant potassium concentration was increased significantly $(107 \%)$ over control especially with the integrated application of biochar and PsJN at $63.9 \mathrm{mg} \mathrm{kg}^{-1}$. However, irrespective to the applied treatments, the $\mathrm{Na}^{+} / \mathrm{K}^{+}$ratio was considerably 
decreased as compared to control (Figure 2). Maximum decrease in $\mathrm{Na}^{+} / \mathrm{K}^{+}$ratio of root, shoot and grain by $64 \%, 87 \%$ and $89 \%$, respectively through combined use of BC and PsJN at $63.9 \mathrm{mg} \mathrm{kg}^{-1}$ as compared to control.
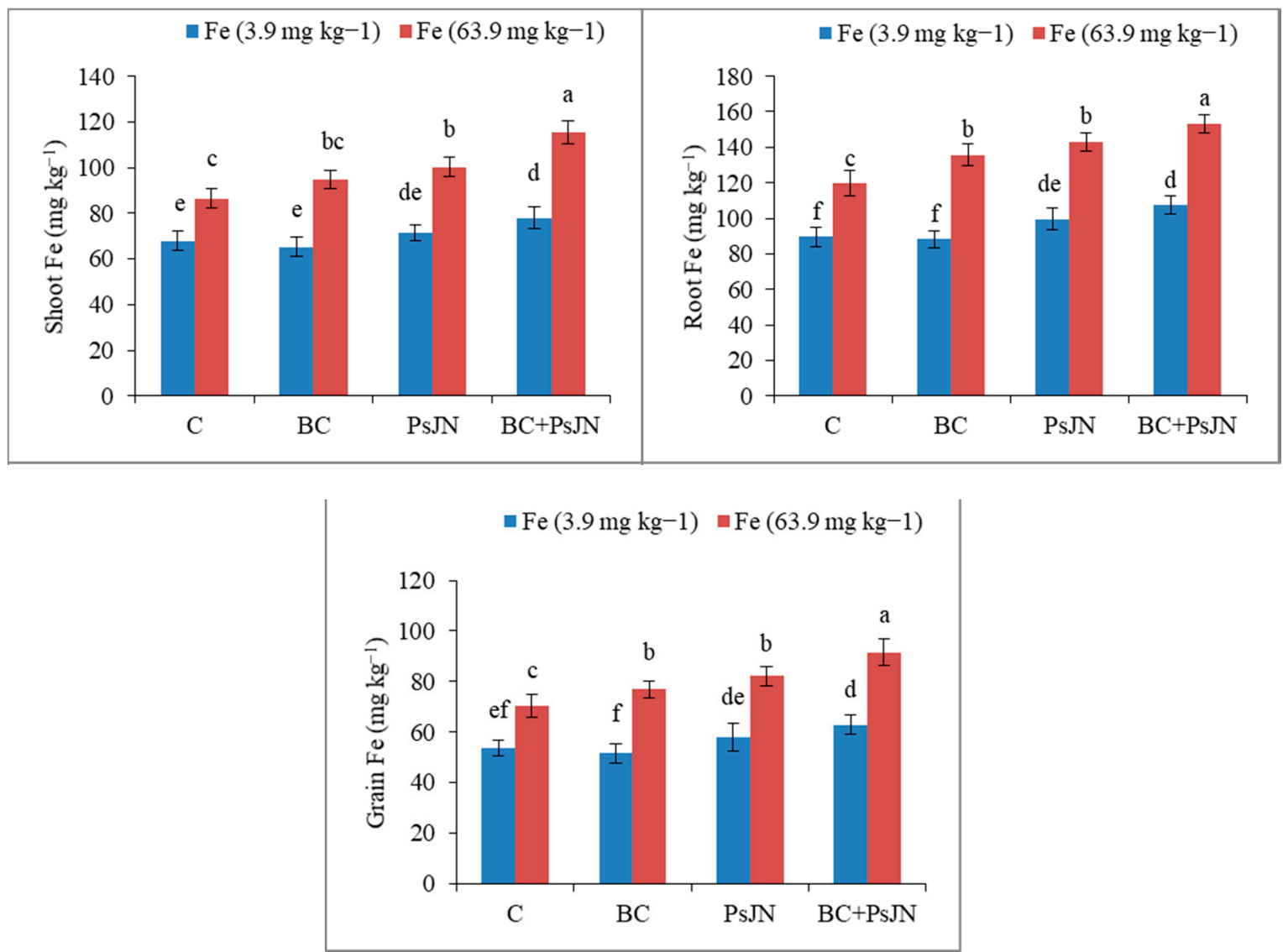

Figure 1. The effect of biochar-Burkholderia phytofirmans PsJN integration on Fe concentration of Chenopodium quinoa under salinity stress. Quantities sharing similar letters are not different with each other. C: Control; BC: Biochar (1\% w/w); PsJN: Burkholderia phytofirmans; Fe: Ferrous sulphate (15 kg $\mathrm{ha}^{-1}$ ). Values are mean of three repeats $\pm \mathrm{SD}$.

Table 3. The effect of biochar-Burkholderia phytofirmans PsJN integration on chemical parameters ( $\mathrm{N}$ and $P$ ) of Chenopodium quinoa under salinity stress.

\begin{tabular}{|c|c|c|c|c|c|c|c|}
\hline Treatment & $\mathrm{Fe}\left(\mathrm{mg} \mathrm{kg}^{-1}\right)$ & $\begin{array}{l}\mathrm{N} \text { in Root } \\
\left(\mathrm{mg} \mathrm{kg}^{-1}\right)\end{array}$ & $\begin{array}{l}\mathrm{N} \text { in Shoot } \\
\left(\mathrm{mg} \mathrm{kg}^{-1}\right)\end{array}$ & $\begin{array}{l}\mathrm{N} \text { in Grain } \\
\left(\mathrm{mg} \mathrm{kg}^{-1}\right)\end{array}$ & $\begin{array}{l}P \text { in Root } \\
\left(\mathrm{mg} \mathrm{kg}^{-1}\right)\end{array}$ & $\begin{array}{l}P \text { in Shoot } \\
\left(\mathrm{mg} \mathrm{kg}^{-1}\right)\end{array}$ & $\begin{array}{c}P \text { in Grain } \\
\left(\mathrm{mg} \mathrm{kg}^{-1}\right)\end{array}$ \\
\hline $\mathrm{C}$ & 3.9 & $21.6 \pm 0.72 \mathrm{~d}$ & $15.8 \pm 0.47 \mathrm{~d}$ & $9.1 \pm 0.23 \mathrm{f}$ & $3.1 \pm 0.15 \mathrm{e}$ & $2.1 \pm 0.10 \mathrm{e}$ & $1.2 \pm 0.06 \mathrm{f}$ \\
\hline \multirow{2}{*}{$\mathrm{BC}$} & 3.9 & $25.2 \pm 0.97 c$ & $17.9 \pm 0.53 c$ & $11.9 \pm 0.32 \mathrm{de}$ & $4.9 \pm 0.26 \mathrm{~cd}$ & $3.5 \pm 0.21 \mathrm{bd}$ & $2.2 \pm 0.09 \mathrm{de}$ \\
\hline & 63.9 & $31.8 \pm 1.18 b$ & $21.9 \pm 0.58 b$ & $14.4 \pm 0.41 \mathrm{c}$ & $6.1 \pm 0.32 \mathrm{ab}$ & $4.8 \pm 0.32 \mathrm{a}$ & $3.7 \pm 0.07 \mathrm{~b}$ \\
\hline \multirow{2}{*}{$\mathrm{BC}+\mathrm{PsJN}$} & 3.9 & $26.1 \pm 0.64 c$ & $18.3 \pm 0.55 c$ & $12.1 \pm 0.34 \mathrm{de}$ & $5.1 \pm 0.30 \mathrm{~cd}$ & $3.8 \pm 0.21 \mathrm{bc}$ & $2.4 \pm 0.07 \mathrm{~d}$ \\
\hline & 63.9 & $35.9 \pm 1.21 \mathrm{a}$ & $25.0 \pm 0.78 \mathrm{a}$ & $17.3 \pm 0.42 \mathrm{a}$ & $6.8 \pm 0.32 \mathrm{a}$ & $5.0 \pm 0.32 \mathrm{a}$ & $4.0 \pm 0.12 \mathrm{a}$ \\
\hline
\end{tabular}

Quantities sharing similar letters are not different with each other. C: Control; BC: Biochar $(1 \% w / w)$; PsJN:

Burkholderia phytofirmans; Fe: Ferrous sulphate $\left(15 \mathrm{~kg} \mathrm{ha}^{-1}\right)$. Values are mean of three repeats $\pm \mathrm{SD}$. 
Table 4. The effect of biochar-Burkholderia phytofirmans PsJN integration on chemical parameters (Na and $\mathrm{K}$ ) of Chenopodium quinoa under salinity stress.

\begin{tabular}{|c|c|c|c|c|c|c|c|}
\hline Treatment & $\mathrm{Fe}\left(\mathrm{mg} \mathrm{kg}^{-1}\right)$ & $\begin{array}{c}\text { Na in Root } \\
\left(\mathrm{mg} \mathrm{kg}^{-1}\right)\end{array}$ & $\begin{array}{l}\text { Na in Shoot } \\
\left(\mathrm{mg} \mathrm{kg}^{-1}\right)\end{array}$ & $\begin{array}{l}\text { Na in Grain } \\
\left(\mathrm{mg} \mathrm{kg}^{-1}\right)\end{array}$ & $\begin{array}{l}\mathrm{K} \text { in Root } \\
\left(\mathrm{mg} \mathrm{kg}^{-1}\right)\end{array}$ & $\begin{array}{l}\mathrm{K} \text { in Shoot } \\
\left(\mathrm{mg} \mathrm{kg}^{-1}\right)\end{array}$ & $\begin{array}{c}\mathrm{K} \text { in Grain } \\
\left(\mathrm{mg} \mathrm{kg}^{-1}\right)\end{array}$ \\
\hline $\mathrm{C}$ & 3.9 & $2.2 \pm 0.06 \mathrm{a}$ & $1.7 \pm 0.05 \mathrm{a}$ & $0.6 \pm 0.06 \mathrm{a}$ & $19.2 \pm 0.64 \mathrm{~d}$ & $11.2 \pm 0.63 \mathrm{e}$ & $7.2 \pm 0.14 \mathrm{f}$ \\
\hline \multirow{2}{*}{$\mathrm{BC}$} & 3.9 & $1.9 \pm 0.05 b c$ & $0.9 \pm 0.03 c$ & $0.4 \pm 0.03 \mathrm{~b}$ & $26.2 \pm 1.18 b c$ & $19.2 \pm 0.83 b c$ & $12.5 \pm 0.34 \mathrm{c}$ \\
\hline & 63.9 & $1.6 \pm 0.05 \mathrm{e}$ & $0.6 \pm 0.03 \mathrm{e}$ & $0.25 \pm 0.02 \mathrm{~cd}$ & $29.3 \pm 1.30 \mathrm{ab}$ & $21.1 \pm 0.86 \mathrm{ab}$ & $13.6 \pm 0.45 b$ \\
\hline \multirow{2}{*}{$\mathrm{BC}+\mathrm{PsJN}$} & 3.9 & $1.8 \pm 0.05 \mathrm{~cd}$ & $0.7 \pm 0.04$ de & $0.3 \pm 0.03 b c$ & $22.6 \pm 0.92 \mathrm{~cd}$ & $15.1 \pm 0.40 \mathrm{~d}$ & $10.1 \pm 0.28 \mathrm{e}$ \\
\hline & 63.9 & $1.3 \pm 0.03 \mathrm{f}$ & $0.4 \pm 0.02 \mathrm{f}$ & $0.2 \pm 0.02 \mathrm{~d}$ & $31.3 \pm 1.52 \mathrm{a}$ & $22.9 \pm 0.98 \mathrm{a}$ & $14.9 \pm 0.36 \mathrm{a}$ \\
\hline
\end{tabular}

Quantities sharing similar letters are not different with each other. C: Control; BC: Biochar (1\% w/w); PsJN: Burkholderia phytofirmans; Fe: Ferrous sulphate $\left(15 \mathrm{~kg} \mathrm{ha}^{-1}\right)$. Values are mean of three repeats \pm SD.
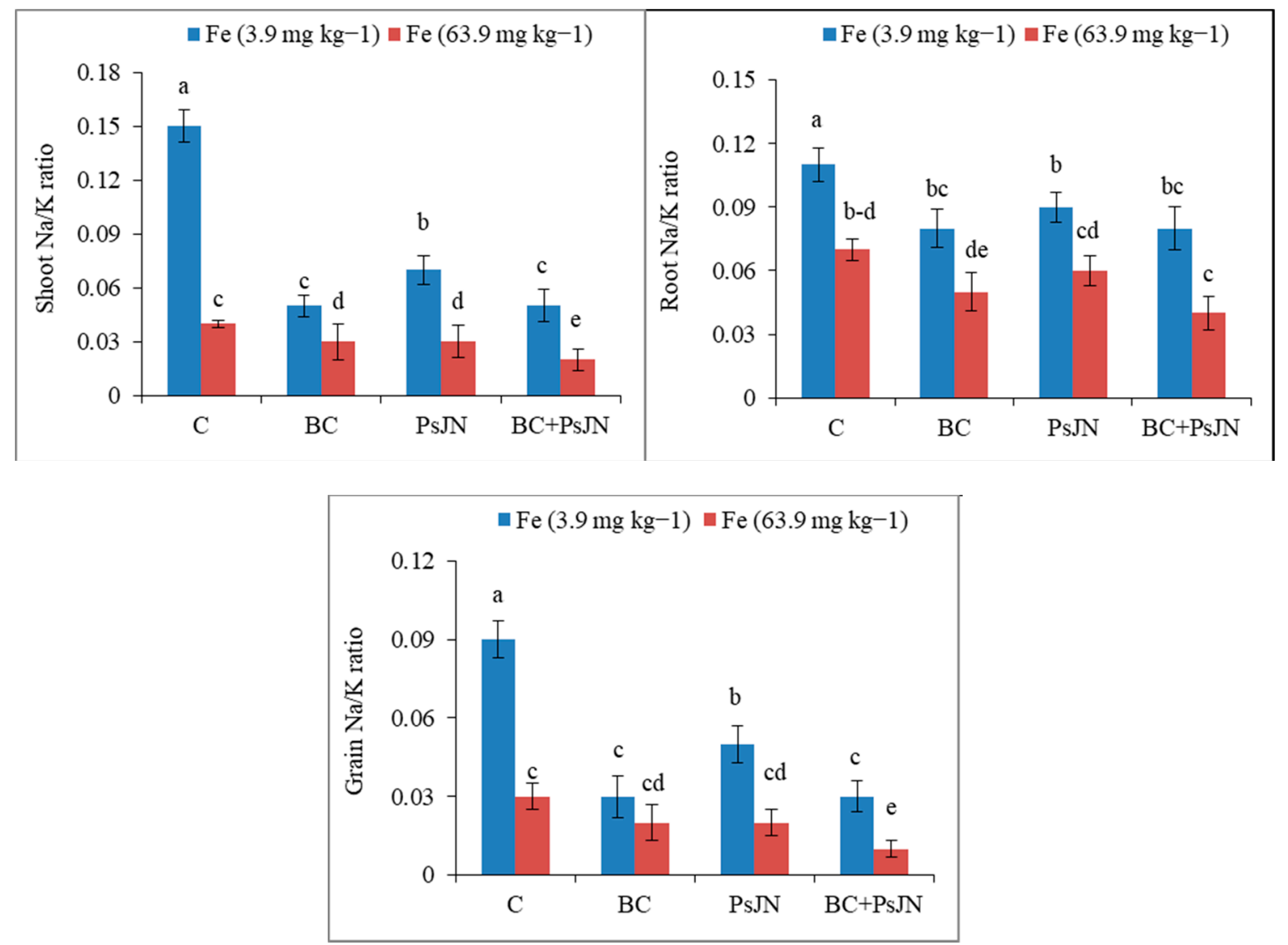

Figure 2. The effect of biochar-Burkholderia phytofirmans PsJN integration on $\mathrm{Na} / \mathrm{K}$ ratio of Chenopodium quinoa tissues under salinity stress. Quantities sharing similar letters are not different with each other. C: Control; BC: Biochar (1\% w/w); PsJN: Burkholderia phytofirmans; Fe: Ferrous sulphate (15 $\left.\mathrm{kg} \mathrm{ha}^{-1}\right)$. Values are mean of three repeats $\pm \mathrm{SD}$.

\subsection{Enzymatic and/Non-Enzymatic Antioxidants and Stress Related Metabolites}

Various assays for enzymatic or non-enzymatic antioxidant activities showed that treatment with biochar and PsJN especially when they were applied together significantly decreased glutathione reductase (GR) activity (61\%), oxidized glutathione (GSSG) activity $(27 \%)$, reduced glutathione (GSH) activity (54\%), GSH-GSSG ratio (38\%), ascorbate peroxidase (APX) activity (45\%), superoxide dismutase (SOD) activity (53\%), glutathione-s-transferase (GST) (56\%), glutathione peroxidase (GPX) (47\%), super-oxide anion (52\%) and malondialdehyde activity (47\%), as compared to control where plants were supplemented with $63.9 \mathrm{mg} \mathrm{kg}^{-1}$ Fe (Figures 3-5). Similarly, sole use of BC showed 
decrease in GR (30\% and 35\%), GSSG (17\% and 20\%), GSH (22\% and 33\%), APX (14\% and 20\%), GPX (7\% and $23 \%)$, SOD (15\% and $34 \%)$, GST ( $25 \%$ and $34 \%)$, super-oxide anion ( $28 \%$ and $32 \%)$ and MDA (5\% and 29\%), respectively at low and high Fe levels relative to their controls. Similarly, single application of PsJN inoculum showed decrease in GR (44\% and $46 \%)$, GSSG (20\% and $22 \%)$, GSH ( $37 \%$ and $43 \%)$, APX (31\% and 33\%), GPX ( $25 \%$ and $34 \%)$, SOD (39\% and $43 \%)$, GST (39\% and $44 \%)$, super-oxide anion ( $42 \%$ and $40 \%$ ) and MDA (13\% and 38\%), respectively at both Fe levels as compared to their controls.
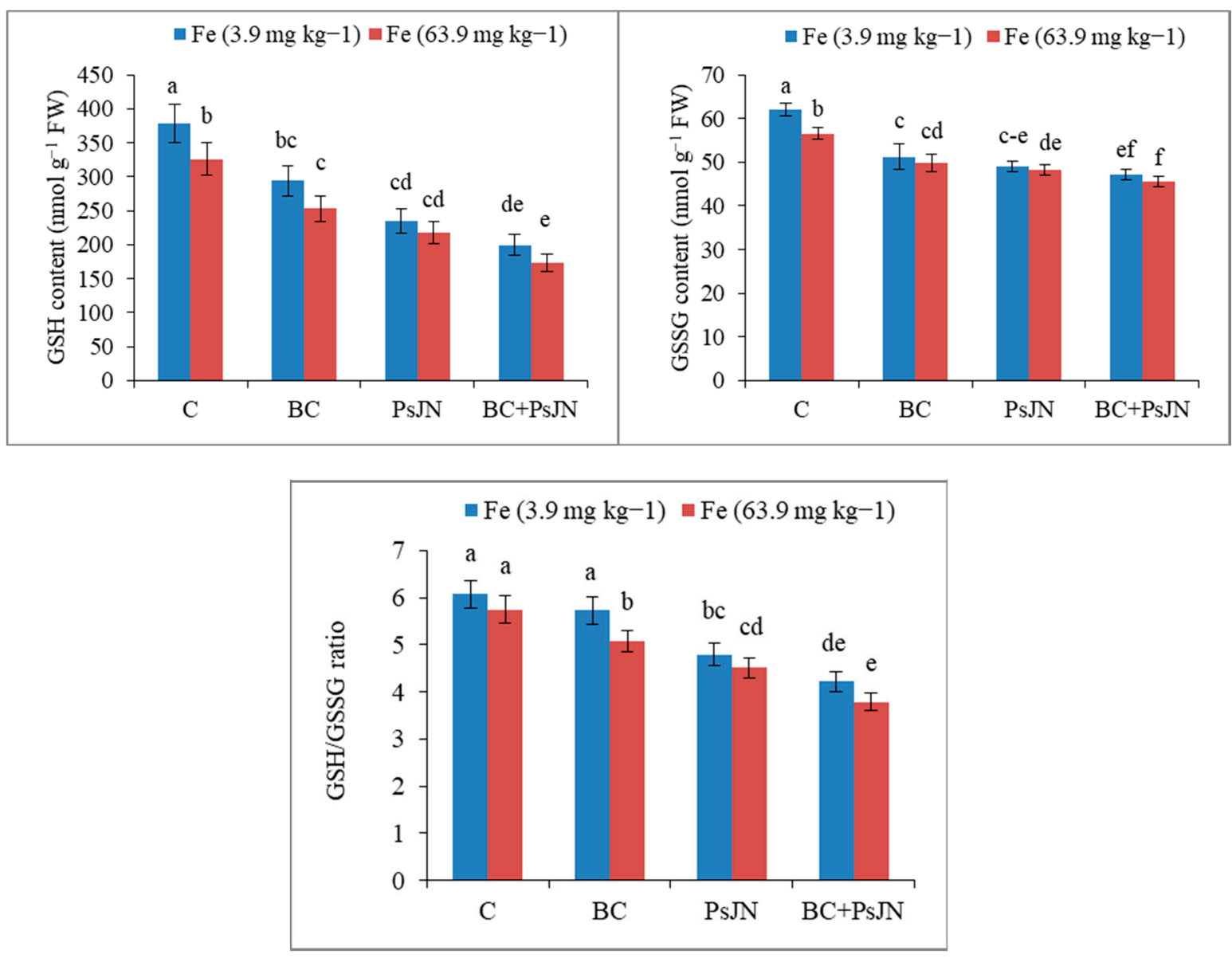

Figure 3. The effect of biochar-Burkholderia phytofirmans PsJN integration on Glutathione homeostasis of Chenopodium quinoa under salinity stress. GSH = Reduced glutathione, GSSG = Oxidized glutathione, GSH/GSS ratio. Quantities sharing similar letters are not different with each other. C: Control; BC: Biochar (1\% w/w); PsJN: Burkholderia phytofirmans; Fe: Ferrous sulphate $\left(15 \mathrm{~kg} \mathrm{ha}^{-1}\right)$. Values are mean of three repeats \pm SD. 

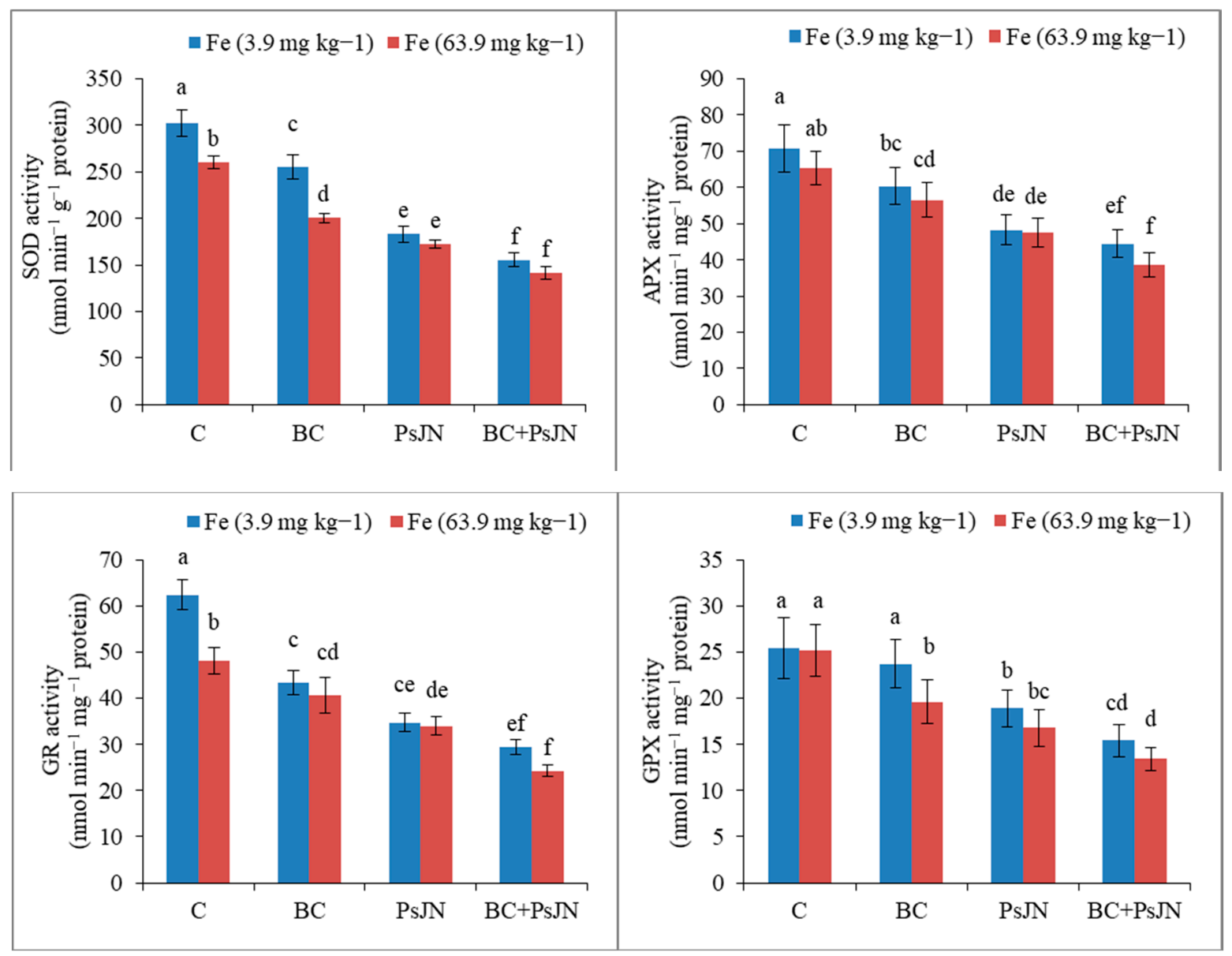

$\square \mathrm{Fe}(3.9 \mathrm{mg} \mathrm{kg}-1) \quad \square \mathrm{Fe}(63.9 \mathrm{mg} \mathrm{kg}-1)$

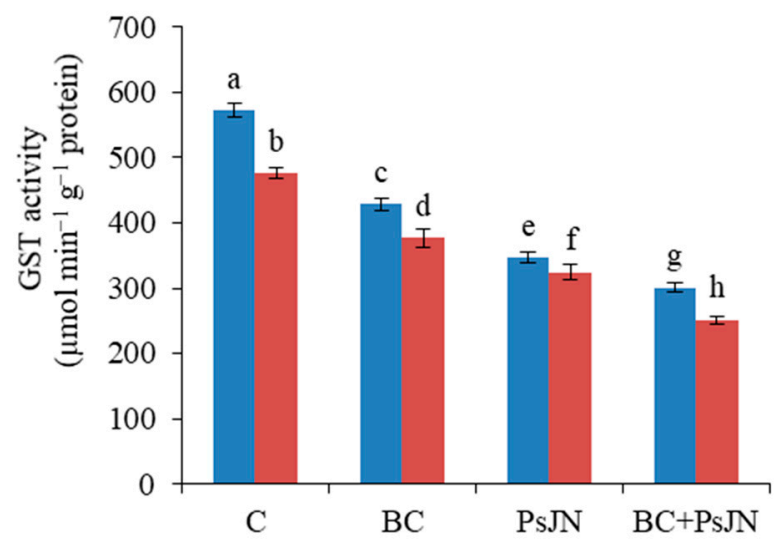

Figure 4. The effect of biochar-Burkholderia phytofirmans PsJN integration on antioxidant activity of Chenopodium quinoa under salinity stress. $\mathrm{SOD}=$ Super-oxide dismutase, $\mathrm{APX}=$ Ascorbate peroxidase, GR = Glutathione reductase, GPX = Glutathione peroxidase, GST = Glutathione S-transferase. Quantities sharing similar letters are not different with each other. C: Control; BC: Biochar (1\% $w / w)$; PsJN: Burkholderia phytofirmans; Fe: Ferrous sulphate $\left(15 \mathrm{~kg} \mathrm{ha}^{-1}\right)$. Values are mean of three repeats $\pm \mathrm{SD}$. 


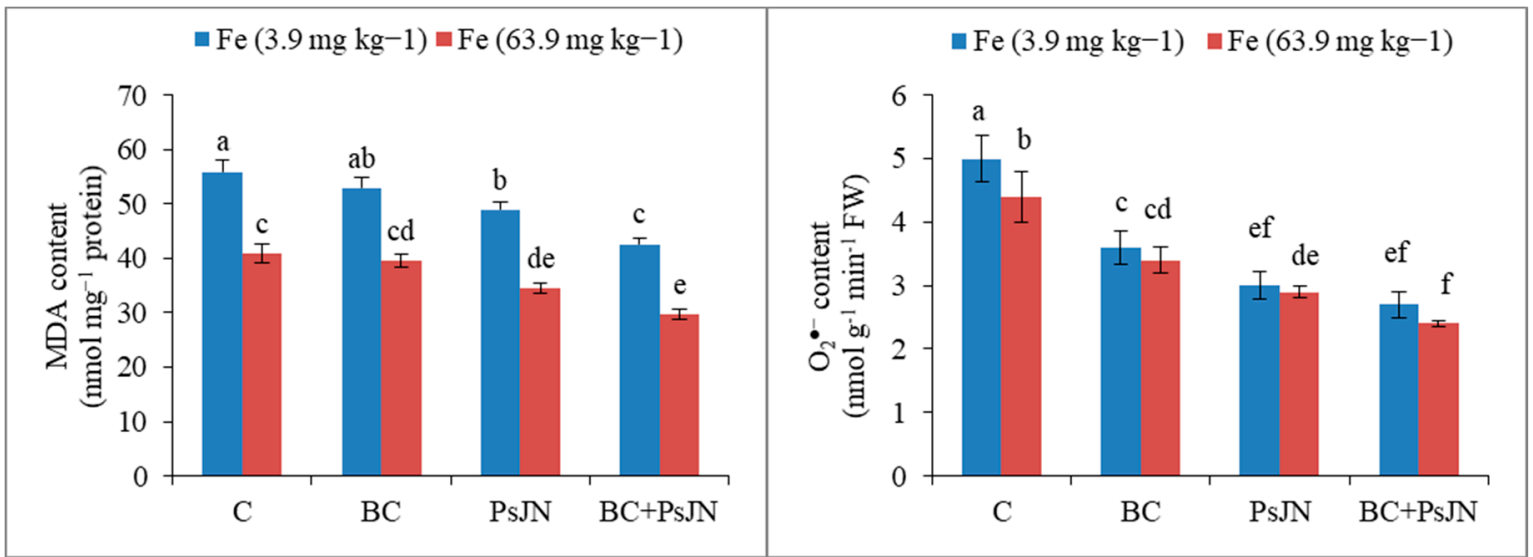

Figure 5. The effect of biochar-Burkholderia phytofirmans PsJN integration on stress related metabolites of Chenopodium quinoa under salinity stress. MDA; Malondialdehyde, $\mathrm{O}_{2}{ }^{-}$; Superoxide anion. Quantities sharing similar letters are not different with each other. C: Control; BC: Biochar ( $1 \% w / w)$; PsJN: Burkholderia phytofirmans; Fe: Ferrous sulphate $\left(15 \mathrm{~kg} \mathrm{ha}^{-1}\right)$. Values are mean of three repeats \pm SD.

\subsection{PsJN Colonization of Rhizosphere, Root, and Shoot}

Efficient colonization of the applied strain was observed in root/shoot interior of quinoa under saline conditions (Figure 6). However, when integrated with biochar and $\mathrm{Fe}$, the persistence of PsJN was more enhanced relative to sole inoculation in the rhizosphere and tissues of quinoa plants. Inoculation combined with biochar showed $2.73 \times 10^{5} \mathrm{CFU} \mathrm{g}^{-1}$ rhizosphere, $9.92 \times 10^{4} \mathrm{CFU} \mathrm{g}^{-1}$ root interior and $1.95 \times 10^{4} \mathrm{CFU} \mathrm{g}^{-1}$ shoot interior bacterial population. However, most $\mathrm{CFU} \mathrm{g}{ }^{-1}$ dry weight of the inoculant strain was recovered from the rhizosphere $\left(5.73 \times 10^{5}\right)$, root interior $\left(4.53 \times 10^{5}\right)$, and shoot interior $\left(9.92 \times 10^{4}\right)$ in the presence of biochar and Fe.

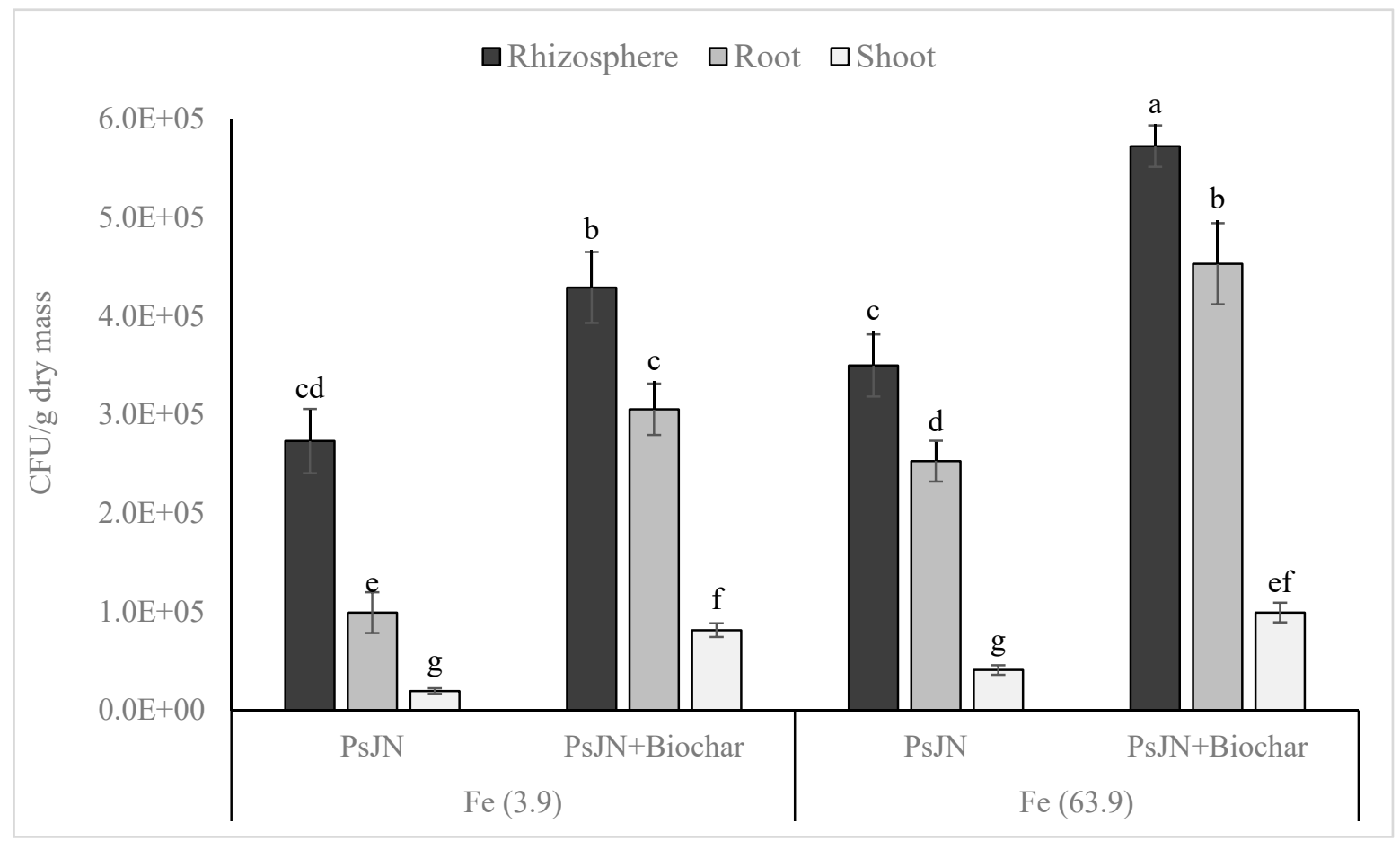

Figure 6. Persistence of selected endophytic strain in the shoot interior of Chenopodium quinoa under salinity stress. C: Control; BC: Biochar ( $1 \% w / w)$; PsJN: Burkholderia phytofirmans; Fe: Ferrous sulphate $\left(15 \mathrm{~kg} \mathrm{ha}^{-1}\right)$. Values are mean of three repeats \pm SD. 


\section{Discussion}

\subsection{Plant Growth Parameters}

Iron is a significant element for normal plant growth and development because it is a cofactor of numerous metabolic reactions, and its deficiency can adversely affect plant growth, photosynthesis, and respiration. Plants growing in saline soils often show typical symptoms of iron deficiency (chlorosis), as the solubility of iron (Fe) in the soil solution decreases with high $\mathrm{pH}$ [49]. In current experiment, we examined the effect of endophytic bacterium Burkholderia phytofirmans PsJN and organic amendment (biochar) on the growth, physiology, and iron-fortification of an emerging crop quinoa in saline soil. BC and PsJN application alone and in combination improved the plant growth, nutrient uptake, and antioxidant homeostasis apart from conferring salinity tolerance in plants. However, these effects were more significant with the combined application of biochar and PsJN. Salinity stress has been known to limit plant growth and yield through disturbing various physiological processes of crops [50]. We found significant reduction in growth attributes (plant height, shoot and root dry weights) of Chenopodium quinoa under saline conditions. However, application of biochar and Burkholderia phytofirmans PsJN significantly improved plant growth in the present study. This improvement in growth of plants might be associated with solubilization of nutrients from biochar [51]. This might also be due to the role of biochar and applied bacteria that have resulted in rhizosphere acidification leading to desorption of nutrients from biochar surface and /or soil colloids and thus have stimulated the growth attributes [31,51-53]. These observations are supported by previous studies, where siderophore producing bacteria including PsJN (which secrete hydroxamate-containing siderophore such as pyoverdin) often reported enhanced plant growth by facilitating Fe uptake and mediating plant tolerance against various abiotic stresses [13,54,55]. Moreover, biochar is known to play a critical role in iron biofortification of cereals in $\mathrm{pH}$ affected calcareous [22] as well as saline soils [56]. Biochar addition enhances nutrients availability to crops, increase water holding capacity of the soil and enhance microbial activity which might increase plant biomass accumulation under stressed conditions [57].

\subsection{Plant Physiological and Biochemical Attributes}

While it is well established that, water stressed plants close their stomata and ultimately lower the gaseous exchange attributes [58] and hence reduced photosynthetic activity. The influence on photosynthesis can be assessed from the influence on photosynthetic pigments. It has been described in certain studies that salinity stress causes decline in photosynthetic pigments of plants $[50,59,60]$. We found decreased physiological attributes in stressed plants. This reduction in physiological parameters might be attributable to disturbed metabolic machinery of the plants under stress [61]. It may also be due to increased osmotic stress in plants that causes shortage of water for plants and reduced rate of transpiration [62]. However, integrated application of biochar and PsJN improved physiological parameters such as stomatal conductance, photosynthetic rate, chlorophyll contents and transpiration rate in present study. By virtue of its high cation exchange capacity, biochar might have increased the availability of essential nutrients to stressed plants and hence enhanced physiological adaptations of quinoa plants under stress [63]. Moreover, bacterial inoculation can have a positive effect on plant physiology through uplifting chlorophyll contents, stomatal conductance, internal $\mathrm{CO}_{2}$ concentration and relative water contents [31,64-67]. Certain PGPB have been recognized in imparting salinity resistance through direct stimulation of crops by providing fixed N, Fe sequestered by bacterial cells, phytohormones and soluble phosphates [11,68,69].

Enhanced crop productivity and improved nutritional quality grown on degraded soils are proposed to be the best solutions to combat malnutrition and hidden hunger [70,71]. Quinoa seeds are distinguished from cereals probably due to significant source of essential amino acids, vitamins and macro- and micro- nutrients [72,73]. Previously, several reports demonstrated reduced nutritional quality of quinoa grown on salt-affected soils $[61,74,75]$. In current study, plants grown on saline soil 
showed significant reduction in nutritional parameters, however, the application of biochar and PsJN significantly improved nutritional attributes. This enhancement of nutritional status of amended plants might be due to the better provision of nutrients through biochar and endophytic bacteria $[31,64]$ which might have helped plants to better adjust under unfavorable growth conditions [76].

\subsection{Nutrients Homeostasis}

Plant salinity tolerance capacity has been correlated with increased $\mathrm{K}^{+}$and decreased $\mathrm{Na}^{+}$ uptake, which ultimately affects the $\mathrm{Na}^{+} / \mathrm{K}^{+}$ratio in plants [77]. PGPB are well known to produce exopolysaccharides which can bind $\mathrm{Na}^{+}$and thereby reduce its uptake by the plants [10]. Because the strain PsJN has the potential to produce exopolysaccharides, therefore, its inoculation in present study decreased the contents of $\mathrm{Na}^{+}$available for plant uptake. These results are substantiated by Nadeem et al. [68], where inoculation of wheat seedlings with exopolysaccharide producing bacteria restricted $\mathrm{Na}^{+}$uptake and stimulated plant growth under saline condition. This may also be attributed to the higher $\mathrm{Na}^{+}$adsorption on surface of applied biochar. These results are in excellent agreement with [78], they reported enhanced growth of rice plants grown under salt-affected soil conditions due to synergistic application of biochar and PGPR.

Moreover, it is well known fact that $\mathrm{Na}^{+}$in higher levels hinders the uptake of other essential nutrients [79]. We found higher concentrations of macro nutrients especially nitrogen, phosphorous and potassium in plants amended with biochar and PSJN alone or in combination as compared to un-amended plants. These findings are in line with other studies describing increased availability of nutrients under the application of organic amendments $[60,80]$. Several other studies have confirmed the involvement of organic amendments (biochar and composts) in improved nutritional status of crops under saline soils due to increased soil aggregate stability, enhanced CEC, improved water retention, improved aeration and organic matter content [81,82]. In addition, we found increased contents of Fe in plants amended with biochar and PSJN relative to control. Previously, it was reported that inoculation of PGPR can facilitate uptake of micronutrients and increase plant tolerance against stress [83-85]. Moreover, Plant growth-promoting bacteria (PGPB) can mobilize the nutrients through various mechanism such as production of organic acids, rhizospheric acidification, nutrients chelation and by multiple exchange reactions $[11,86]$. It has been reported that PsJN is well-known PGPB, having many functional traits for plant growth promotion, nutrient uptake, and stress tolerance. PsJN found to be producing siderophores, indole acetic acid (IAA) and synthesis of ACC deaminase and its genome sequencing revealed that this strain harbors numerous genes for these traits and equipped with other important PGPB functions $[13,87]$. The synthesized siderophores release into the soil, bind iron and facilitate its uptake through TonB-dependent Fe-siderophore complex receptors [88]. Very recently, Shahid et al. [12] reported enhanced growth of rice through up-regulation of stress responsive genes due to inoculation of PGPR (Achromobacter sp. FB-14) showing ACC deaminase activity. Moreover, the production or modulation of plant hormones such as indole acetic acid and ethylene as well as nutrient solubilizing ability explain the possible mechanism of plant growth promotion of quinoa by PsJN.

\subsection{Antioxidant Homeostasis}

Under abiotic stress conditions, plant produce certain ROS such as hydrogen peroxide, superoxide, and hydroxyl radicals [89]. To avoid oxidative stress by scavenging ROS, plants are equipped with antioxidant defense characterized by various metabolites and enzymes. Among various enzymes, APX plays a critical role as powerful antioxidant $\mathrm{H}_{2} \mathrm{O}_{2}$-scavenger $[90,91]$. The antioxidants are produced under the stimuli of various stresses (such as salinity and other abiotic stress), and their concentration is frequently characterized as an assessment of oxidative stress. PsJN harbor numerous genes for ROS tolerance such as glutathione-S-transferases (GST), catalases, hydroperoxide reductases, superoxide, dismutases, and peroxidases [13]. In the present study, enzymatic antioxidants activities decreased especially by combined utilization of biochar and PsJN under saline condition. Our results are supported by the findings of Kanwal et al. [92] where biochar reduced the negative effects of salinity by 
decreasing superoxide dismutase in wheat. Very recently, Saeed et al. [31] reported that combined use of endophytic bacteria along with amendment reverted the harmful effects of abiotic stress on Brassica napus growth by decreasing the activities of certain studied antioxidants.

\subsection{Persistence of Endophyte in Shoot, Root and Rhizosphere}

The persistence and activity of bacterial strain are governed by multifarious environmental factors (e.g., salinity). In this study, PsJN was found to be able to compete with the indigenous microbiota and effectively persisted in the plant environment (Figure 6) apart from promoting plant growth and nutrient uptake under saline environment. However, higher endophytic populations were observed in the soil treated with biochar, the viability of endophytic bacteria was further increased in the Fe enriched saline environment. The reason for the greater colonization of PsJN strain in BC amended soil might be due to availability of plentiful nutrients for normal microbial growth, provision of niches and shelter from predators. Moreover, microbial inoculation may have helped plants to meet their nutrient requirements under diverse environmental conditions [76]. Furthermore, Naveed et al. [93] demonstrated that under stressed conditions, plants undertake multiple metabolic and osmotic adjustments resulting in altered root exudation, which could affect the colonization and efficacy of bacterial inoculum. Moreover, PsJN strain harbor a wide range of genes for motility, chemotaxis, surface adhesion and quorum sensing which explain its ability of successful colonization in a variety of stressed environments [13]. The positive impact of biochar on soil microbial population and nutrient supply might explain the reason why the integrated application of biochar and PsJN perform best in our study.

\section{Conclusions}

The research findings suggested that the integrated application of Burkholderia phytofirmans PsJN and biochar have great ability to shed beneficial impacts on Fe bioavailability, growth, yield and nutritional value of quinoa grains grown in iron-limited saline conditions. The combined use of PsJN, BC and Fe enhanced growth, physiology, and mineral nutrition by alleviating salinity-induced oxidative stress as depicted by reduced antioxidants activity and $\mathrm{Na}^{+} / \mathrm{K}^{+}$ratio of $C$. quinoa. The use of siderophore producing microbes with organic amendments might be a promising, sustainable and low-cost strategy for tackling micronutrient deficiencies in the low-and middle-income countries. Moreover, this approach can easily be integrated into the existing farming system to achieve food fortification with micronutrients.

Author Contributions: Conceptualization: M.N., M.Y., M.X.; Data curation: N.R., A.M., B.N.; Formal analysis and software: N.R., B.N. and M.H.; Investigation: Z.A., W.S., N.S.; Methodology: M.N., A.M., M.Y. and W.S.; Supervision: M.N.; Writing—original draft: M.N. and N.R.; Writing—review \& editing: A.S., A.M., M.H., N.S. and M.X. All authors have read and agreed to the published version of the manuscript.

Funding: This study received no external funding.

Acknowledgments: Authors are highly grateful to the administration of Institute of Soil \& Environmental Sciences (ISES), University of Agriculture Faisalabad-Pakistan for provision of research facilities.

Conflicts of Interest: The authors declare no conflict of interest.

\section{References}

1. Beard, J.L. Why iron deficiency is important in infant development. J. Nutr. 2008, 138, 2534-2536. [CrossRef]

2. Yang, Z.; Lu, W.; Long, Y.; Bao, X.; Yang, Q. Assessment of heavy metals contamination in urban topsoil from Changchun City, China. J. Geochem. 2011, 108, 27-38. [CrossRef]

3. Thurnham, D.I. Nutrition of adolescent girls in low- and middle-income countries. Sight Life 2013, $27,26-37$.

4. Murgia, I.; Arosio, P.; Tarantino, D.; Soave, C. Biofortification for combating 'hidden hunger' for iron. Trends Plant Sci. 2012, 17, 47-55. [CrossRef]

5. Rana, A.; Joshi, M.; Prasanna, R.; Shivay, Y.S.; Nain, L. Biofortification of wheat through inoculation of plant growth promoting rhizobacteria and cyanobacteria. J. Soil Biol. 2012, 50, 118-126. [CrossRef] 
6. Boukhalfa, H.; Crumbliss, A.L. Chemical aspects of siderophore mediated iron transport. Biometals 2002, 15, 325-339. [CrossRef]

7. Celik, H.; Katkat, A.V. Some parameters in relation to iron nutrition status of peach orchards. J. Biol. Environ. Sci. 2007, 1, 111-115.

8. Cifuentes, F.R.; Lindemann, W.C. Organic matter stimulation of elemental sulfur oxidation in a calcareous soil. Soil Sci. Soc. Am. J. 1993, 57, 727-731. [CrossRef]

9. Glick, B.R.; Penrose, D.M.; Li, J.P. A model for the lowering of plant ethylene concentrations by plant growth-promoting bacteria. J. Theor. Biol. 1998, 190, 63-68. [CrossRef] [PubMed]

10. Ashraf, M.; Hasnain, S.; Berge, O.; Mahmood, T. Inoculating wheat seedlings with exopolysaccharide-producing bacteria restricts sodium uptake and stimulates plant growth under salt stress. Biol. Fertil. Soils 2004, 40, 157-162. [CrossRef]

11. Ali, M.A.; Naveed, M.; Mustafa, A.; Abbas, A. The good, the bad and the ugly of rhizosphere microbiome. In Probiotics and Plant Health; Springer: Singapore, 2017; pp. 253-290.

12. Shahid, M.; Shah, A.A.; Basit, F.; Noman, M.; Zubair, M.; Ahmed, T.; Naqqash, T.; Manzoor, I.; Maqsood, A. Achromobacter sp. FB-14 harboring ACC deaminase activity augmented rice growth by upregulating the expression of stress-responsive CIPK genes under salinity stress. Braz. J. Microbiol. 2019, 1-10. [CrossRef] [PubMed]

13. Mitter, B.; Petric, A.; Shin, M.W.; Chain, P.S.; Hauberg-Lotte, L.; Reinhold-Hurek, B.; Sessitsch, A. Comparative genome analysis of Burkholderia phytofirmans PsJN reveals a wide spectrum of endophytic lifestyles based on interaction strategies with host plants. Front. Plant Sci. 2013, 4, 120. [CrossRef] [PubMed]

14. McCauley, A.; Jones, C.; Jacobsen, J. Soil pH and Organic Matter; Nutrient Management Modules 8, \#4449e8; Montana State University Extension Service: Bozeman, MT, USA, 2009; pp. 1-12.

15. Xu, G.; Wei, L.L.; Sun, J.N.; Shao, H.B.; Chang, S.X. What is more important for enhancing nutrient bioavailability with biochar application into a sandy soil: Direct or indirect mechanism? Ecol. Eng. 2013, 52, 119-124. [CrossRef]

16. Jeffery, S.; Bezemer, T.M.; Cornelissen, G.; Kuyper, T.W.; Lehmann, J.; Mommer, L.; Sohi, S.P.; van de Voorde, T.F.J.; Wardle, D.A.; Van Groenigen, J.W. The way forward in biochar research: Targeting trade-offs between the potential wins Glob. Chang. Biol. Bioenerg. 2015, 7, 1-13. [CrossRef]

17. Kappler, A.; Wuestner, M.L.; Ruecker, A.; Harter, J.; Halama, M.; Behrens, S. Biochar as an electron shuttle between bacteria and Fe (III) minerals. Environ. Sci. Technol. Lett. 2014, 1, 339-344. [CrossRef]

18. Razzaghi, F.; Ahmadi, S.H.; Adolf Jensen, V.I.; Jacobsen, C.R.; Andersen, S.E.M.N. Water relations and transpiration of quinoa (Chenopodium quinoa Willd.) under salinity and soil drying. J. Agron. Crop Sci. 2011, 197, 348-360. [CrossRef]

19. Razzaghi, F.; Ahmadi, S.H.; Jacobsen, S.E.; Jensen, C.R.; Andersen, M.N. Effects of salinity and soil-drying on radiation use efficiency, water productivity and yield of quinoa (Chenopodium quinoa Willd.). J. Agron. Crop Sci. 2012, 198, 173-184. [CrossRef]

20. Ruiz, K.B.; Biondi, S.; Martinez, E.A.; Orsini, F.; Antognoni, F.; Jacobsen, S.E. Quinoa-A model crop for understanding salt-tolerance mechanisms in halophytes. Plant Biosys. Int. J. 2015, 150, 357-371. [CrossRef]

21. Bashir, K.; Takahashi, R.; Nakanishi, H.; Nishizawa, N.K. The road to micronutrient biofortification of rice: Progress and prospects. Front. Plant Sci. 2013, 4, 15. [CrossRef]

22. Ramzani, P.M.A.; Khalid, M.; Naveed, M.; Ahmad, R.; Shahid, M. Integrating the organic amendment with iron fertilization for improving productivity and Fe biofortification in rice under acidified calcareous soil. Pak. J. Agri. Sci. 2016, 53. [CrossRef]

23. Aziz, M.Z.; Yaseen, M.; Abbas, T.; Naveed, M.; Mustafa, A.; Hamid, Y.; Saeed, Q.; Ming-gang, X.U. Foliar application of micronutrients enhance crop stand, yield and the biofortification essential for human health of different wheat cultivars. J. Integr. Agric. 2018, 18, 1369-1376. [CrossRef]

24. Connorton, J.M.; Balk, J. Iron biofortification of staple crops: Lessons and challenges in plant genetics. Plant Cell Physiol. 2019, 60, 1447-1456. [CrossRef] [PubMed]

25. Gee, G.W.; Bauder, J.W. Particle Size Analysis by Hydrometer: A simplified method for routine textural analysis and a sensitivity test of measurement parameters. Soil Sci. Soc. Am. J. 1979, 43, 1004-1007. [CrossRef]

26. Lindsay, W.L.; Norvell, W.A. Development of a DTPA soil test for zinc, iron, manganese and copper. Soil. Sci. Soc. Am. J. 1978, 42, 421-428. [CrossRef] 
27. Watanabe, F.S.; Olsen, S.R. Test of an ascorbic acid method for determining phosphorus in water and $\mathrm{NaHCO}_{3}$ extracts from soil. Soil Sci. Soc. Am. J. 1965, 291, 677-678. [CrossRef]

28. Bremner, J.M.; Mulvaney, C.S. Nitrogen total. In Methods of Soil Analysis, 2nd ed.; Page, A.L., Ed.; Part 2: Chemical and Microbiological Properties; American Society of Agronomy: Madison, WI, USA, 1982; pp. 595-624.

29. Richards, L.A. Diagnosis and improvement of saline and alkali soils. In Agriculture Handbook; US Department of Agriculture: Washington, DC, USA, 1954; p. 60.

30. Sanchez, M.E.; Lindao, E.; Margaleff, D.; Martınez, O.; Moran, A. Pyrolysis of agricultural residues from rape and sunflowers: Production and characterization of biofuels and biochar soil management. J. Anal. Appl. Pyrol. 2009, 85, 142-144. [CrossRef]

31. Saeed, Z.; Naveed, M.; Imran, M.; Bashir, M.A.; Sattar, A.; Mustafa, A.; Xu, M. Combined use of Enterobacter sp. MN17 and zeolite reverts the adverse effects of cadmium on growth, physiology and antioxidant activity of Brassica napus. PLoS ONE 2019, 14, e0213016. [CrossRef]

32. Smith, I.K.; Vierheller, T.L.; Thorne, C.A. Assay of glutathione reductase in crude tissue homogenates using 5, 5'-dithiobis (2-nitrobenzoic acid). Anal. Biochem. 1998, 175, 408-413. [CrossRef]

33. Griffiths, O.W. Determination of glutathione and glutathione disulphide using glutathione reductase and 2vinyl pyridine. Anal. Briochem. 1980, 106, 207-212. [CrossRef]

34. Nakano, Y.; Asada, K. Hydrogen peroxide is scavenged by ascorbate-specific peroxidase in spinach chloroplasts. Plant Cell Physiol. 1981, 22, 867-880.

35. Roth, E.F.; Gilbert, H.S. The pyrogallol assay for superoxide dismutase: Absence of a glutathione artifact. Anal. Biochem. 1984, 137, 50-53. [CrossRef]

36. Habig, W.H.; Pabst, M.J.; Jakoby, W.B. Glutathione-S-transferase, the first enzymatic step in mercapturic acid formation. J. Biol. Chem. 1974, 249, 7130-7139. [PubMed]

37. Elstner, E.F.; Heupel, A. Inhibition of nitrite formation from hydroxyl ammonium-chloride: A simple assay for superoxide dismutase. Anal. Biochem. 1976, 70, 616-620. [CrossRef]

38. Jambunathan, N. Determination and detection of reactive oxygen species (ROS), lipid peroxidation, and electrolyte leakage in plants. In Plant Stress Tolerance, Methods in Molecular Biology 639; Sunkar, R., Ed.; Humana Press: Totowa, NJ, USA; Springer: Berlin, Germany, 2010; pp. 291-297.

39. Reiter, B.; Pfeifer, U.; Schwab, H.; Sessitsch, A. Response of endophytic bac-terial communities in potato plants to infection with Erwinia carotovora subsp. atroseptica. Appl. Environ. Microbiol. 2002, 68, 2261-2268. [CrossRef] [PubMed]

40. Mayak, S.; Tirosh, T.; Glick, B.R. Plant growth-promoting bacteria that confer resistance to water stress in tomatoes and peppers. Plant Sci. 2004, 166, 525-530. [CrossRef]

41. Yang, G.; Rhodes, D.; Joly, R.J. Effect of high temperature on membrane stability and chlorophyll fluorescence in glycinebetaine-containing maize lines. Aust. J. Plant Physiol. 1996, 23, 431-443.

42. Sairam, R.K.; Rao, K.V.; Srivastava, G.C. Differential response of wheat genotypes to long term salinity stress in relation to oxidative stress, antioxidant activity and osmolyte concentration. Plant Sci. 2002, 163, 1037-1046. [CrossRef]

43. Bradford, M.M. A rapid and sensitive method for the quantitation of microgram quantities of protein utilizing the principle of protein-dye binding. Anal. Biochem. 1976, 72, 248-254. [CrossRef]

44. Haug, W.; Lantzsch, H.J. Sensitive method for the rapid determination of phytate in cereals and cereal products. J. Sci. Food Agric. 1983, 34, 1423-1424. [CrossRef]

45. AOAC. Official Methods of Analysis of the Association of Official's Analytical Chemists, 17th ed.; Association of Official Analytical Chemists: Arlington, WV, USA, 2003.

46. Wolf, B. The comprehensive system of leaf analysis and its use for diagnosing crop nutrient status. Commun. Soil Sci. Plant Anal. 1982, 13, 1035-1059. [CrossRef]

47. Jones, J.R.J.; Case, V.W. Sampling, handling, and analyzing plant tissue samples. In Soil Testing and Plant Analysis; Westerman, R.L., Ed.; Soil Science Society of America: Madison, WI, USA, 1990; pp. 389-428.

48. Ashraf, M.Y.; Khan, A.H.; Azmi, A.R. Cell membrane stability and its relation with some physiological process in wheat. Acta Agron. Hung. 1992, 41, 183-191.

49. Kakei, Y.; Ishimaru, Y.; Kobayashi, T.; Yamakawa, T.; Nakanishi, H.; Nishizawa, N.K. OsYSL16 plays a role in the allocation of iron. Plant Mol. Biol. 2012, 79, 583-594. [CrossRef] [PubMed] 
50. Shahzad, H.; Ullah, S.; Iqbal, M.; Bilal, H.M.; Shah, G.M.; Ahmad, S.; Zakir, A.; Ditta, A.; Farooqi, M.A.; Ahmad, I. Salinity types and level-based effects on the growth, physiology and nutrient contents of maize (Zea mays). Ital. J. Agron. 2019, 14, 199-207. [CrossRef]

51. Paradelo, R.; Vazquez-Nion, D.; Silva, B.; Gonzalez, A.; Barral, M.T. Acidification of mixtures of granite powder and compost for reuse in plant production. Compost. Sci. Util. 2016, 24, 1-10. [CrossRef]

52. Silber, A.; Levkovitch, I.; Graber, E.R. pH-dependent mineral release and surface properties of corn straw biochar: Agronomic implications. Environ. Sci. Technol. 2010, 44, 9318-9323. [CrossRef]

53. Akram, M.; Ashraf, M.Y.; Ahmad, R.; Waraich, E.A.; Iqbal, J.; Mohsan, M. Screening for salt tolerance in maize (Zea mays L.) hybrids at an early seedling stage. Pak. J. Bot. 2010, 42, 141-154.

54. Zhao, S.; Wei, H.; Lin, C.-Y.; Zeng, Y.; Tucker, M.P.; Himmel, M.E.; Ding, S.-Y. Burkholderia phytofirmans inoculation-induced changes on the shoot cell anatomy and iron accumulation reveal novel components of Arabidopsis-endophyte interaction that can benefit downstream biomass deconstruction. Front. Plant Sci. 2016, 7. [CrossRef]

55. Sheibani-Tezerji, R.; Rattei, T.; Sessitsch, A.; Trognitz, F.; Mitter, B. Transcriptome Profiling of the Endophyte Burkholderia phytofirmans PsJN Indicates Sensing of the Plant Environment and Drought Stress. mBio 2015, 6, e00621-15. [CrossRef]

56. Ramzani, P.M.A.; Khalid, M.; Naveed, M.; Ahmad, R.; Shahid, M. Iron biofortification of wheat grains through integrated use of organic and chemical fertilizers in $\mathrm{pH}$ affected calcareous soil. Plant Physiol. Biochem. 2016, 104, 284-293. [CrossRef]

57. Lehmann, J.; Rillig, M.C.; Thies, J.; Masiello, C.A.; Hockaday, W.C.; Crowley, D. Biochar effects on soil biota: A review. Soil Biol. Biochem. 2011, 43, 1812-1836. [CrossRef]

58. Ache, P.; Bauer, H.; Kollist, H.; Al-Rasheid, K.A.; Lautner, S.; Hartung, W.; Hedrich, R. Stomatal action directly feeds back on leaf turgor: New insights into the regulation of the plant water status from non-invasive pressure probe measurements. Plant J. 2010, 62, 1072-1082. [CrossRef] [PubMed]

59. Taffouo, V.D.; Kouamou, J.K.; Ngalangue, L.M.T.; Ndjeudji, B.A.N.; Akoa, A. Effects of salinity stress on growth, ions partitioning and yield of some cowpea (Vigna ungiuculata L., walp) cultivars. Int. J. Bot. 2009, 5, 135-143.

60. Niamat, B.; Naveed, M.; Ahmad, Z.; Yaseen, M.; Ditta, A.; Mustafa, A.; Rafique, M.; Bibi, R.; Sun, N.; Xu, M. Calcium-Enriched Animal Manure Alleviates the Adverse Effects of Salt Stress on Growth, Physiology and Nutrients Homeostasis of Zea mays L. Plants 2019, 8, 480. [CrossRef] [PubMed]

61. Bascunan-Godoy, L.; Reguera, M.; Abdel-Tawab, Y.M.; Blumwald, E. Water deficit stress-induced changes in carbon and nitrogen partitioning in Chenopodium Wild. Planta 2016, 243, 591-603. [CrossRef]

62. Gong, X.L.; Liu, C.; Zhou, M.; Luo, L.Y.; Wang, L.; Wang, Y.; Hong, M.M.; Cai, J.W.; Gong, S.J.; Hong, F.S. Oxidative damages of maize seedlings caused by combined stress of potassium deficiency and salt stress. Plant Soil. 2011, 340, 443-452. [CrossRef]

63. Graber, E.R.; Tsechansky, L.; Lew, B.; Cohen, E. Reducing capacity of water extracts of biochars and their solubilization of soil Mn and Fe. Eur. J. Soil Sci. 2014, 65, 162-172. [CrossRef]

64. Naveed, M.; Mustafa, A.; Azhar, S.Q.; Kamran, M.; Zahir, Z.A.; Núñez-Delgado, A. Burkholderia phytofirmans $\mathrm{PsJN}$ and tree twigs derived biochar together retrieved $\mathrm{Pb}$-induced growth, physiological and biochemical disturbances by minimizing its uptake and translocation in mung bean (Vigna radiata L.). J Environ. Manag. 2020, 257, 109974. [CrossRef]

65. Sandhya, V.; Ali, S.Z.; Grover, M.; Reddy, G.; Venkateswarlu, B. Effect of plant growth promoting Pseudomonas spp. on compatible solutes, antioxidant status and plant growth of maize under drought stress. Plant Growth Reg. 2010, 62, 21-30. [CrossRef]

66. Vardharajula, S.; Ali, S.Z.; Grover, M.; Reddy, G.; Bandi, V. Drought-tolerant plant growth promoting Bacillus spp.: Effect on growth, osmolytes, and antioxidant status of maize under drought stress. J. Plant Int. 2011, 6, 1-14.

67. Yandigeri, M.S.; Meena, K.K.; Singh, D.; Malviya, N.; Singh, D.P.; Solanki, M.K.; Yadav, A.K.; Arora, D.K. Drought-tolerant endophytic actinobacteria promote growth of wheat (Triticum aestivum) under water stress conditions. Plant Growth Reg. 2012, 68, 411-420. [CrossRef]

68. Rodriguez, H.; Fraga, R. Phosphate solubilizing bacteria and their role in plant growth promotion. Biotechnol. Adv. 1999, 17, 319-339. [CrossRef] 
69. Hayat, R.; Ali, S.; Amara, U.; Khalid, R.; Ahmed, I. Soil beneficial bacteria and their role in plant growth promotion: A review. Ann. Microbiol. 2010, 60, 579-598. [CrossRef]

70. Hirich, A.; Choukr-Allah, R.; Jacobsen, S.E. The combined effect of deficit irrigation by treated wastewater and organic amendment on quinoa (Chenopodium quinoa Willd.) productivity. Desalin. Water Treat. 2014, 52, 2208-2213. [CrossRef]

71. Sattar, A.; Naveed, M.; Ali, M.; Zahir, Z.A.; Nadeem, S.M.; Yaseen, M.; Meena, V.S.; Farooq, M.; Singh, R.; Rahman, M.; et al. Perspectives of potassium solubilizing microbes in sustainable food production system: A review. Appl. Soil Ecol. 2019, 133, 146-159. [CrossRef]

72. FAO. Home-International Year of Quinoa 2013. Available online: http://www.fao.org/quinoa-2013/en/ (accessed on 15 January 2020).

73. Nowak, V.; Du, J.; Charrondiere, U.R. Assessment of the nutritional composition of quinoa (Chenopodium quinoa Willd.). Food Chem. 2016, 193, 47-54. [CrossRef] [PubMed]

74. Yang, A.; Akhtar, S.S.; Iqbal, S.; Amjad, M.; Naveed, M.; Zahir, Z.A.; Jacobsen, S.-E. Enhancing salt tolerance in quinoa by halotolerant bacterial inoculation. Funct. Plant Biol. 2016, 43, 632-642. [CrossRef]

75. Amjad, M.; Akhtar, J.; Anwar-ul-Haq, M.; Yang, A.; Akhtar, S.S.; Jacobsen, S.E. Integrating role of ethylene and ABA in tomato plants adaptation to salt stress. Sci. Hortic. Amst. 2014, 172, 109-116. [CrossRef]

76. Mustafa, A.; Naveed, M.; Saeed, Q.; Ashraf, M.N.; Hussain, A.; Abbas, T.; Kamran, M.; Minggang, X. Application Potentials of Plant Growth Promoting Rhizobacteria and Fungi as an Alternative to Conventional Weed Control Method. In Crop Production; Intechopen: London, UK, 2019.

77. Jeschke, W.D.; Wolf, O. External potassium supply is not required for root growth in saline conditions: Experiments Withricinus communis L. grown in a reciprocal split-root system. J. Exp. Bot. 1988, 39, 1149-1167. [CrossRef]

78. Hafez, E.M.; Alsohim, A.S.; Farig, M.; Omara, A.E.D.; Rashwan, E.; Kamara, M.M. Synergistic Effect of Biochar and Plant Growth Promoting Rhizobacteria on Alleviation of Water Deficit in Rice Plants under Salt-Affected Soil. Agronomy 2019, 9, 847. [CrossRef]

79. Gao, S.; Ouyang, C.; Wang, S.; Xu, Y.; Tang, L.; Chen, F. Effects of salt stress on growth, antioxidant enzyme and phenylalanine ammonia-lyase activities in Jatropha curcas L. seedlings. Plant Soil Environ. 2008, 54, 374-381. [CrossRef]

80. Singh, J.S.; Pandey, V.C.; Singh, D.P.; Singh, R.P. Influence of pyrite and farmyard manure on population dynamics of soil methanotroph and rice yield in saline rain-fed paddy field. Agric. Ecosyst. Environ. 2010, 139, 74-79. [CrossRef]

81. Amini, S.; Ghadiri, H.; Chen, C.; Marschner, P. Salt-affected soils, reclamation, carbon dynamics, and biochar: A review. J. Soil Sediment. 2016, 16, 939-953. [CrossRef]

82. Oo, A.N.; Iwai, C.B.; Saenjan, P. Soil properties and maize growth in saline and nonsaline soils using cassava-industrial waste compost and vermicompost with or without earthworms. Land Degrad. Dev. 2015, 26, 300-310. [CrossRef]

83. Spaepen, S.; Dobbelaere, S.; Croonenborghs, A.; Vanderleyden, J. Effects of Azospirillum brasilense indole-3-acetic acid production on inoculated wheat plants. Plant Soil 2008, 312, 15-23. [CrossRef]

84. Pourbabaee, A.A.; Shoaibi, F.; Emami, S.; Alikhani, H.A. The potential contribution of siderophore producing bacteria on growth and Fe ion concentration of sunflower (Helianthus annuus L.) under water stress. J. Plant Nutr. 2018, 41, 619-626. [CrossRef]

85. Sharma, S.; Chandra, S.; Kumar, A.; Bindraban, P.; Saxena, A.K.; Pande, V.; Pandey, R. Foliar application of iron fortified bacteriosiderophore improves growth and grain Fe concentration in wheat and soybean. Ind. J. Microbiol. 2019, 59, 344-350. [CrossRef]

86. Chung, H.; Park, M.; Madhaiyan, M.; Seshadri, S.; Song, J.; Cho, H.; Sa, T. Isolation and characterization of phosphate solubilizing bacteria from the rhizosphere of crop plants of Korea. Soil Biol. Biochem. 2005, 37, 1970-1974. [CrossRef]

87. Sessitsch, A.; Coenye, T.; Sturz, A.V.; Vandamme, P.; Ait Barka, E.; Faure, D.; Reiter, B.; Glick, B.R.; Wang-Pruski, G.; Nowak, J. Burkholderia phytofirmans sp. nov., a novel plant associated bacterium with plant beneficial properties. Int. J. Syst. Evol. Microbiol. 2005, 55, 1187-1192. [CrossRef]

88. Miethke, M.; Marahiel, M.A. Siderophore-Based iron acquisition and pathogen control. Microbiol. Mol. Biol. Rev. 2007, 71, 413-451. [CrossRef] 
89. Zafar, S.A.; Hameed, A.; Nawaz, M.A.; Wei, M.; Noor, M.A.; Hussain, M.; Rehman, M. Mechanisms and molecular approaches for heat tolerance in rice (Oryza sativa L.) under climate change scenario. J. Integr. Agric. 2018, 17, 726-738. [CrossRef]

90. Sgherri, C.; Ranieri, A.; Quartacci, M.F. Antioxidative responses in Vitis vinifera infected by grapevine fanleaf virus. J. Plant Physiol. 2013, 170, 121-128. [CrossRef] [PubMed]

91. Quartacci, M.F.; Ranieri, A.; Sgherri, C. Antioxidative defence mechanisms in two grapevine (Vitis vinifera L.) cultivars grown under boron excess in the irrigation water. Vitis 2015, 54, 51-58.

92. Kanwal, S.; Ilyas, N.; Shabir, S.; Saeed, M.; Gul, R.; Zahoor, M.; Mazhar, R. Application of biochar in mitigation of negative effects of salinity stress in wheat (Triticum aestivum L.). J. Plant Nutr. 2018, 41, 526-538. [CrossRef]

93. Naveed, M.; Mitter, B.; Reichenauer, T.G.; Wieczorek, K.; Sessitsch, A. Increased drought stress resilience of maize through endophytic colonization by Burkholderia phytofirmans PsJN and Enterobacter sp. FD17. Environ. Exp. Bot. 2014, 9, 30-39. [CrossRef]

(C) 2020 by the authors. Licensee MDPI, Basel, Switzerland. This article is an open access article distributed under the terms and conditions of the Creative Commons Attribution (CC BY) license (http://creativecommons.org/licenses/by/4.0/). 